\title{
On the identities of Cryxus Leach, 1814 and Zepbronia Gray, 1832, the oldest generic names in the millipede order Sphaerotheriida (Diplopoda)
}

\section{Об идентичности Cryxus Leach, 1814 и Zepbronia Gray, 1832, старейших родовых названиях у многоножек отряда Sphaerotheriida (Diplopoda)}

\author{
S.I. Golovatch ${ }^{1}$, T. Wesener ${ }^{2}$, J.-P. Mauriès ${ }^{3}$, I.I. Semenyuk ${ }^{1}$ \\ С.И. Головач ${ }^{1}$ Т. Везенер ${ }^{2}$, Ж.-П. Морьес ${ }^{3}$, И.И. Семенюк ${ }^{1}$
}

\footnotetext{
${ }^{1}$ Institute for Problems of Ecology and Evolution, Russian Academy of Sciences, Leninsky prospekt 33, Moscow 119071 Russia. E-mail: sgolovatch@yandex.ru

Институт проблем экологии и эволюции РАН, Ленинский проспект, 33, Москва 119071 Россия.

${ }^{2}$ Zoologisches Forschungsmuseum Alexander Koenig, Adenauerallee 160, D-53113 Bonn, Germany.

${ }^{3}$ Muséum national d'Histoire naturelle, Département Systématique et Evolution, Case Postale 53, 61 rue Buffon, F-75231 Paris Cedex 05, France.
}

KEY WORDS: Diplopoda, Sphaerotheriida, Zephroniidae, Cryxus, Zephronia, taxonomy, neotype, Vietnam.

КЛЮЧЕВЫЕ СЛОВА: Diplopoda, Sphaerotheriida, Zephroniidae, Cryxus, Zephronia, таксономия, неотип, Вьетнам.

ABSTRACT. Based on the selection of neotypes for and detailed redescriptions of Julus ovalis Linnaeus, 1758 and Zephronia ovalis Gray, 1832, both from southern Vietnam, the identities of Cryxus Leach, 1814 and Zephronia Gray, 1832, two oldest generic names in the millipede family Zephroniidae, and in the entire order Sphaerotheriida, have ultimately been clarified.

РЕЗЮМЕ. На основе выделения неотипов и детальных переописаний Julus ovalis Linnaeus, 1758 и Zephronia ovalis Gray, 1832 из Южного Вьетнама, положение в системе Cryxus Leach, 1814 и Zephronia Gray, 1832, двух самых старых родовых названий в семействе Zephroniidae, а также в целом отряде Sphaerotheriida, наконец, удалось прояснить.

\section{Introduction}

At present, the tropical order Sphaerotheriida, or Giant Pill-millipedes, contains more than 320 species from 24 genera and four families: Sphaerotheriidae (confined to southern Africa), Arthrosphaeridae (restricted to Madagascar, Sri Lanka and southern India), Procyliosomatidae (endemic to Australia and New Zealand), and Zephroniidae [Wesener \& VandenSpiegel, 2009; Wesener et al., 2010]. The latter family encompasses over 140 species or subspecies from at least 15 genera. It is strictly Southeast Asian, ranging from the eastern Himalaya in the Northwest, through southern China, Indochina, Malaysia and Indonesia, to the Philippines and Sulawesi in the Southeast [Jeekel, 2001].

It is the taxonomy of Zephroniidae that still remains especially badly confused [Hoffman, 1980; Jeekel,
2001]. In particular, the identity of Cryxus Leach, 1814, the oldest available generic name in the entire order Sphaerotheriida [Leach, 1814], is still unclear, as is that of the type species of Zephronia Gray, 1832, the second oldest genus.

The first sphaerotheriidan to have ever been recognized was Julus ovalis Linnaeus, 1758, one of the 12 millipede species named by Linnaeus [1758]. The original description of $J$. ovalis was most succinct (" 20 legs on each side. Ten oblong-oval trunk segments, excluding thorax and tail" - translated from Latin), and it said the species inhabited "Asia". The animal was also referred to "Chin. lagerstr. 35, f. 4", meaning the dissertation entitled "Chinensia lagerstroemiana" by Odhelius [1754], a pre-1758 work which had been executed under the supervision of Linnaeus. That thesis was later reproduced twice verbatim, in both cases forming Chapter 61 in the same collection of dissertations once supervised by Linnaeus [1759, 1788b]. Figure 4 illustrated Julus ovalis which, like numerous other plants and animals Odhelius redescribed (all validated a year earlier by Linnaeus [1758]), presumably originated from "China" in the broadest sense. Odhelius [Linnaeus, 1759, 1788b] provided a slightly more extended account of $J$. ovalis and indicated "China" as provenance. He also added, "Body almost oval, very smooth, infuscate bluish grey... Head stout, dark, densely punctate... Antennae filiform, enlarged, segment 6 regularly subglobular. 20 legs on each side, compressed, terminating in incurved claws, with a straight spine behind" (translated from Latin). Much more often, however, Linnaeus [1767, 1775, 1788a, 1789] and some of his immediate followers referred to $J$. ovalis as a species living in the "Oceano europaeo" (e.g. Oken [1835]). 
Perhaps the most detailed account of $J$. ovalis is contained in Linné [1775]: "The 'Seevielfuß' (the ocean/ lake-millipede). The body with the exception of the head and tail has 10 segments and 20 pairs of legs. The shape of the first and last shields, which form the head and tail, is similar to a quadrant, the rings are bluish brownish and very smooth. The head is stout, brown and covered with concave punctures. The legs are flat laterally, ending in a bent claw and also have a spine on their upper side. Their home is in the European ocean" (translated from German).

Olivier [1792] provided a slightly different description of $J$. ovalis ("Il a environ un pouce de long. Le corps est ovale, glabre, d'un jaune obscure, un peu livide et composé de douze anneaux. La tête est obtuse, obscure, parsemée de points enfoncés. Les pattes font un nombre de vingt paires, \& terminées par un ongle crochu.") and repeated "l'Océan Européen" as the place of origin of $J$. ovalis. He added the size (about one inch, i.e. approximately $25 \mathrm{~mm}$ ) and modified the coloration into "obscure yellow and slightly blue-grey". Although it is very doubtful that Olivier had restudied the Linnean type(s), most likely he did see a giant pillmillipede!

Based on the above information, virtually any species of Sphaerotheriida (or Glomerida, or even a marine isopod crustacean, as mentioned by Jeekel [2001]) could fit the concept of ovalis in the sense of Linnaeus. To make it worse, Fabricius [1775] misspelled Julus as "Iulus", and the species ovalis as "ovatus" [1775, 1781, 1793], also mentioning the "Oceano europaeo". Latreille $[1804,1810]$ transferred ovalis to his freshly proposed Glomeris Latreille, 1803 (Glomerida), to be followed and narrated by Klug [1810] and Lamarck [1858]. Leach [1814], based on 20, not 16, pairs of legs stated originally as being characteristic of $J$. ovalis, proposed a new genus, Cryxus, to incorporate $J$. ovalis alone. However, the erection of Cryxus had remained unnoticed until Jeekel [1971] revived it from complete oblivion. Indeed, Leach's [1814] texts were mainly English translations from Latreille [1810]. They had been reworked (by D. Brewster) from several of Leach's manuscripts which appeared scattered in several places in a chapter of a rare edition. Moreover, that publication was additionally obscured by much the same, yet shorter, paper by Leach [1817] which appeared a little later, but contained neither Cryxus nor C. ovalis.

Gray [1832] provided a very brief description ("Fulvous. Allied to Glomeri, but formed of 10 rings, with a circular ocellus on each side of the head") and a few drawings of a Zephronia ovalis from an unknown locality. However, since the legend to Plate 135, Figs 5a-c, reads "Zephronia ovalis. - T.E. Gray", Zephronia has since been largely accepted as a valid genus containing a new species, Z. ovalis Gray, 1832, which has nothing to do with Cryxus ovalis. There was no doubt it represented a giant pill-millipede.

Brandt [1833], based on several species he simultaneously described from southern Africa, proposed the next two new genera of Sphaerotheriida: Sphaerotherium Brandt, 1833, the type genus of Sphaerotheriidae, as well as Sphaeropoeus Brandt, 1833, both properly typified much later [Pocock, 1895]. Brandt [1841] argued the priority of Zephronia over Sphaerotherium, having transferred Z. ovalis to his genus he dated 1831 . But the report Brandt quoted had only been an oral presentation read at the Russian Academy of Sciences in St. Petersburg in August 1831. Hence, that was no true publication that would render any taxonomic effect [Golovatch \& Hoffman, 2001]. Later on, Brand [1844] referred to J. ovalis as a dubious species, and to Zephronia as a junior synonym of his Sphaeropoeus.

In contrast, Newport [1844a, 1844b, 1856], followed by Butler [1873], referred to Zephronia as a senior synonym of Sphaeropoeus (leaving Sphaerotherium distinct) and, without any arguments, to $Z$. ovalis Gray, 1832 as a senior synonym of $Z$. insignis (Brandt, 1833), with Java as its provenance. He might have been the last to see type material of $Z$. ovalis in the British Museum, London. Gervais [1837, 1844, 1847] and Lucas [1842] synonymized both Sphaerotherium and Sphaeropoeus with Zephronia, Gervais [1847] ultimately admitting Sphaerotherium as only a section of Zephronia, and confusingly referring to Z. ovalis Gray, 1832 as a synonym of either the invalidly proposed species Z. javanica [Gervais, 1837] or the slightly older $Z$. insignis. In contrast, Lucas [1842] considered $Z$. ovalis Gray, 1832 as a valid species devoid of synonyms. Koch [1847, 1863], strangely enough, regarded both Sphaerotherium and Sphaeropoeus as senior synonyms of Zephronia. Silvestri [1897] listed several genera in Zephroniidae, but he, too, obviously considered Zephronia as a junior synonym of Sphaerotherium. Butler [1873], Latzel [1884] and Preudhomme de Borre [1884] recognized Sphaerotherium and Zephronia as two valid genera. In the latest revision of Zephronia, Pocock [1899a, 1899b] failed to relocate the type(s) of $Z$. ovalis to incorporate this species into his key. Pocock [1895] was also the first author to view Zephronia and Sphaeropoeus as separate genera.

Both Hoffman [1980] and, especially, Jeekel [2001] have treated the taxonomic problems concerning both Cryxus and Zephronia in due detail. They both admit that, since type material of Julus ovalis and Zephronia ovalis seems to have long been lost, the nomenclature of Zephroniidae, and of the Sphaerotheriida as a whole, would be finally stabilized only through neotype selection. Hoffman [1980] suspects Gray [1832] might have actually created Zephronia for Julus ovalis Linnaeus, 1758, in which case this genus would immediately become an objective junior synonym of Cryxus. But then the nearly 40 species of the erstwhile Zephronia would remain unclassified. In contrast, Jeekel [2001] suggests selecting neotypes of Cryxus ovalis and Zephronia ovalis to maintain these genera separately, considering the current usage of Zephronia as a genus, in which species show at least two apical spines on the tarsi. Furthermore, Jeekel [2001] proposes to pick up a species of Zephroniidae with several 
Table 1. A history of the classification of the oldest generic names in giant pill-millipedes.

Таблица 1. История классификации старейших родовых названий у диплопод-сферотериид.

\begin{tabular}{|c|c|c|c|c|c|c|c|c|}
\hline Genus & Brandt & Newport & Gervais & $\begin{array}{l}\text { C.L. } \\
\text { Koch }\end{array}$ & $\begin{array}{l}\text { Butder/ } \\
\text { Latzel/ } \\
\text { de Borre }\end{array}$ & Pocock* & $\begin{array}{l}\text { Hoffman } \\
1980\end{array}$ & Jeekel 2001 \\
\hline $\begin{array}{l}\text { Cryxus Leach, } \\
1814\end{array}$ & - & - & - & - & - & - & Cryxus & Cryxus \\
\hline $\begin{array}{l}\text { Zephronia } \\
\text { Gray, } 1832\end{array}$ & $\begin{array}{l}\text { Junior } \\
\text { synonym of } \\
\text { Sphaerothe- } \\
\text { rium [1844] }\end{array}$ & $\begin{array}{l}\text { Possibly a } \\
\text { senior } \\
\text { synonym of } \\
\text { Sphaero- } \\
\text { poeus }\end{array}$ & Zephronia & - & Zephronia & Zephronia & Zephronia & Zephronia \\
\hline $\begin{array}{l}\text { Sphaerothe- } \\
\text { rium Bra ndt, } \\
1833\end{array}$ & $\begin{array}{l}\text { New genus } \\
{[1833]}\end{array}$ & $\begin{array}{l}\text { Sphaerothe- } \\
\text { rium }\end{array}$ & $\begin{array}{l}\text { Sub genus } \\
\text { (=Sectio) of } \\
\text { Zephronia } \\
\text { (1847 } \\
\text { only!) }\end{array}$ & $\begin{array}{l}\text { Senior } \\
\text { synonym } \\
\text { of } \\
\text { Zephronia }\end{array}$ & $\begin{array}{l}\text { Sphaerothe- } \\
\text { rium }\end{array}$ & $\begin{array}{l}\text { Sphaero the- } \\
\text { rium }\end{array}$ & $\begin{array}{l}\text { Sphaero the- } \\
\text { rium }\end{array}$ & $\begin{array}{l}\text { Sphaerothe- } \\
\text { rium }\end{array}$ \\
\hline $\begin{array}{l}\text { Sphaeropoeus } \\
\text { Brandt, } 1833\end{array}$ & $\begin{array}{l}\text { New genus } \\
{[1833]}\end{array}$ & - & $\begin{array}{l}\text { Junior } \\
\text { synonym of } \\
\text { Zephronia }\end{array}$ & $\begin{array}{l}\text { Senior } \\
\text { synonym of } \\
\text { Zephronia }\end{array}$ & $\begin{array}{l}\text { Junior } \\
\text { synonym of } \\
\text { Zephronia }\end{array}$ & Sphaeropoeus & Sphaeropoeus & Sphaeropoeus \\
\hline
\end{tabular}

* Pocock [1894] was apparently the first author to treat Sphaeropoeus and Zephronia as separate genera, a notion followed by almost all later authors.

* Очевидно, Pocock [1894] был первым, кто рассматривал Sphaeropoeus и Zephronia в качестве самостоятельных родов, точка зрения, разделенная большинством более поздних авторов.

apical spines from the Malay Peninsula to fix the concept of Cryxus ovalis as type-species of Cryxus, and Zephronia nigrinota Butler, 1872, from the eastern Himalaya of India, to designate it as type-species of Zephronia.

To summarize, both Cryxus and Zephronia, the oldest available generic names not only in the family Zephroniidae, but in the entire order Sphaerotheriida, have long required their type species to be clarified through a proper selection of material. Since the catalogue by Jeekel [2001] is fairly complete and accurate, we shall repeat it hereafter mainly as regards original descriptions of taxa. We disagree with such a choice of possible neotypes, however, because nearly any zephroniid from Southeast Asia, best represented by fresh samples good enough not only for careful redescriptions of morphological characters, but also for molecular analyses, fits our aims. Even though the original description of $Z$. ovalis stated the animal as being brown, this feature can easily be neglected, as almost any dry material would appear at least somewhat infuscate, brown to black. The same would also concern neotype selection for Cryxus ovalis.

The confusing taxonomic history of the oldest generic names in Sphaerotheriida is summarized above in a tabular form (Table 1).

Our paper focuses on neotype selections for and detailed descriptions of Cryxus ovalis (Linnaeus, 1758) and Zephronia ovalis Gray, 1832, based on material from the Cat Tien National Park, southern Vietnam. This nature reserve is known to support at least 36 species of Diplopoda, one of the richest millipede faunules globally [Semenyuk et al., 2011; Golovatch et al., 2011]. Among them, four species belong in Zephroniidae, the remaining two to be described elsewhere. In our descriptions, we follow the most detailed pattern recently advanced by Wongthamwanich et al. [2012].
Thus, the nomenclature of the family Zephroniidae, as well as of the order Sphaerotheriida, becomes fully stabilized.

\section{Material and methods}

Collection: Material was taken during long-term ecological and faunistic research in the Cat Tien National Park, a patch of lowland monsoon tropical woodland in southern Vietnam $\left(11^{\circ} 21^{\prime}-11^{\circ} 48^{\prime} \mathrm{N}, 107^{\circ}\right.$ $\left.10^{\prime}-107^{\circ} 34^{\prime} \mathrm{E}\right)$ [Golovatch et al., 2011].

Illustrations: For SEM, specimens were dried via alcohol chain $(85 \%, 90 \%, 95 \%, 2 \times 100 \%)$, mounted on sticky-stubs and dried overnight in a desiccator. For observation on a Hitachi S2460 N (based at the ZFMK) they were sputtered with gold for 120 seconds. After analysis, objects were removed from the stubs, re-hydrated in ethanol, and put into microvials together with the specimen.

DNA extraction and sequencing: Total genomic DNA was extracted from muscle tissue laterally interconnecting the midbody tergites using the DNAeasy Blood \& Tissue kit from Qiagen following the manufacturer's extraction protocol. The mitochondrial cytochrome $c$ oxidase subunit I (COI) gene was amplified using polymerase chain reaction (PCR) [Saiki et al. 1988] and using the HCO/LCO primer pair (LCO1490, HCO-2198, Folmer et al. [1994]), as well as the Nancy \& LCO primer pair [Simon et al., 1994]. PCR protocols were similar to those utilized previously [Wesener et al., 2010] in Sphaerotheriida. Purified PCR products were outsourced for double-strand sequencing to a contract sequencing facility (Macrogen, Seoul, Korea) on an ABI3730 XL automatic DNA sequencer, using the same primer sets as for PCR. Sequencing reads were assembled with Bioedit 7.1.3. [Hall, 1999], while the identity of all sequences was confirmed with 


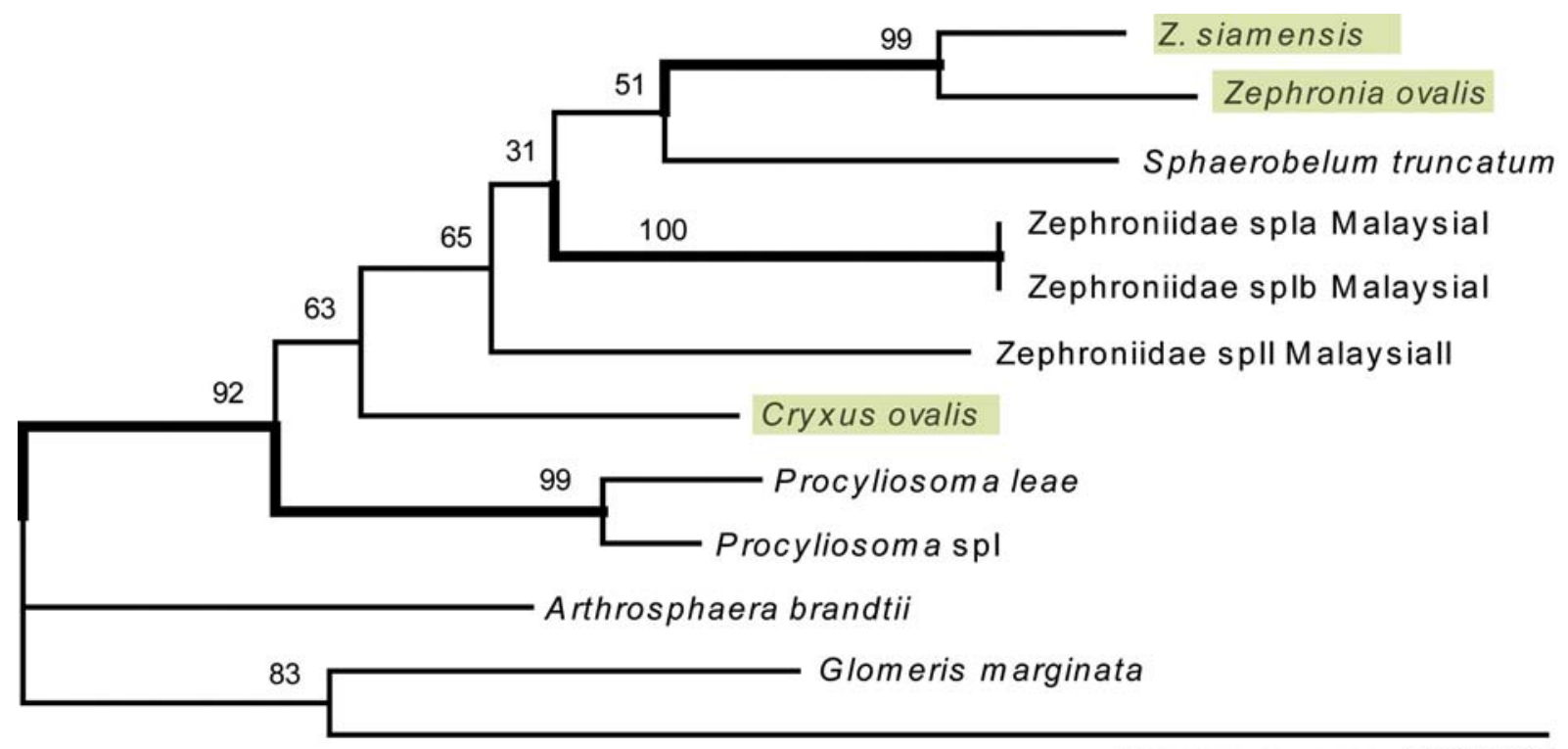

Doratogonus sp. GG-2003

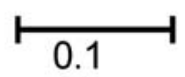

Fig. 1. Maximum likelihood tree of the COI analysis. Bootstrap values (1,000 replicates) given above branches. Thicker branches with $>90 \%$ bootstrap support. Species highlighted in green were newly sequenced in this study.

Рис. 1. Древо максимального сходства при анализе СОI. Величины начальной загрузки (1000 повторностей) даны выше ветвей. Более толстые ветви поддержаны с более 90\% начальной загрузки. Виды, выделенные зеленым, секвенированы впервые в настоящем исследовании.

BLAST searches [Altschul et al., 1997]. The number of obtained base pairs of Zephronia ovalis and Z. siamensis Hirst, 1911 was 674, while the first 53 bp did not amplify for Cryxus ovalis. All three sequences were submitted to GenBank (Accession numbers: JX486067, JX486068, JX486069).

The COI sequences were aligned by hand with COI sequences of different giant pill-millipede genera obtained during previous studies [Wesener et al., 2010, Wongthamwanich et al., 2012], including all known COI sequences of members of the family Zephroniidae, three sequences from other Sphaerotheriida families (Procyliosomatidae and Arthrosphaeridae), as well as of the genus Doratogonus Attems, 1914 (Spirostreptida: Spirostreptidae) and the species Glomeris marginata (Villers, 1789) (Glomerida: Glomeridae). The latter two taxa were used to root the trees. All sequences except those of Zephronia ovalis, Z. siamensis Hirst, 1907 and Cryxus ovalis were downloaded from GenBank, for access codes and exact localities see Table 2, fasta and nexus files of the dataset can be requested from the second author.

DNA analysis: Mean pairwise distances (Table 3) between terminals (transformed into percentages) were determined using MEGA5.05 [Tamura et al., 2011]. A maximum parsimony analysis was undertaken. The small number of taxa $(\mathrm{n}=12)$ allowed an 'exhaustive' maximum parsimony analysis under the 'Alltrees' criterion to be conducted with PAUP* v. 4.0b [Swofford, 2002]. The dataset includes a total of 247 parsimony informative characters. A single shortest tree of length 914 was found (tree not shown). Statistical support of the splits was observed with a 1000 replicate bootstrap analysis, also conducted in PAUP.

For the maximum likelihood analysis, a model selection was undertaken with MEGA5.05. The implemented Bayesian information criterion (BIC) selected the General Time Reversible model with gamma-distribution [Nei \& Kuma, 2000], GTR+G, as best-fitting nucleotide substitution model $(-\operatorname{lnL}=3384.17946$, freq $\mathrm{A}=0.2684$, freqC $=0.2314$, freqG $=0.1593$, freq $\mathrm{T}$ $=0.341$ ). Maximum likelihood analyses were conducted in MEGA5. The bootstrap consensus tree (Fig. 1) inferred from 1000 replicates [Felsenstein, 1985] is taken to represent the evolutionary history of the analyzed taxa. All positions containing gaps and missing data were eliminated. There was a total of 608 positions in the final dataset.

While the data do not allow an interpretation of the obtained trees in a phylogenetic context (more and especially nuclear genes would be needed for that), it is useful to highlight the genetic distances between the different species and genera of Zephroniidae.

\section{Results}

DISTANCE ANALYSIS. The distance analysis is based on a previous matrix of Zephroniidae and outgroups [Wongthamwanich et al., 2012] to which sequences of three species, Z. siamensis, Z. ovalis, and 
Table 2. Specimen information and GenBank accession numbers. Species marked by an asterisk were sequenced for this analysis.

Таблица 2. Информация об экземплярах и принятые номера Генбанка. Экземпляры, отмеченные звездочкой, секвенированы для этого анализа.

\begin{tabular}{|l|l|l|}
\hline Species & Voucher \# & $\begin{array}{l}\text { Genbank } \\
\text { Accession \# }\end{array}$ \\
\hline Spirostreptida, Doratogonus sp. GG-2003 & unknown & AY288738 \\
\hline Glomerida, Glomeris marginata & ZFMK Myr 009 & FJ409909 \\
\hline Sphaerotheriida, unknown family, Epicyliosoma sp. GB & unknown & AF370841 \\
\hline Sphaerotheriida, Procyliosomatidae, Procyliosoma leae & QVMAG 23:45801 & FJ409910 \\
\hline Sphaerotheriida, Procyliosomatidae, Procyliosoma sp. & QVMAG 23:25721 & FJ409911 \\
\hline Sphaerotheriida, Arthrosphaeridae, Arthrosphaer brandti & FMNH-INS 8650 & FJ409915 \\
\hline Sphaerotheriida, Zephroniidae sp. Ia (Zephronia sp.) & ZFMK Myr 014 & FJ409912 \\
\hline Sphaerotheriida, Zephroniidae sp. Ib (Zephronia sp.) & ZFMK Myr 015 & FJ409913 \\
\hline Sphaerotheriida, Zephroniidae sp. II (unknown genus) & lost & FJ409914 \\
\hline Sphaerotheriida, Zephroniidae, Sphaerobelum truncatum & FMNH-INS 72673 & JN885184 \\
\hline *Sphaerotheriida, Zephroniidae, Zephronia siamensis (topotype) & FMNH-INS-72669 & JX486067 \\
\hline *Sphaerotheriida, Zephroniidae, Zephronia ovalis & ZFMK Myr 0832 & JX486068 \\
\hline *Sphaerotheriida, Zephroniidae, Cryxus ovalis & ZFMK Myr 0824 & JX486069 \\
\hline
\end{tabular}

Table 3. Uncorrected genetic distances (in \%). For more taxonomic information see Table 2. Таблица 3. Неисправленные генетические расстояния (в \%). Более детальную таксономическую информацию см. в

\begin{tabular}{|c|l|c|c|c|c|c|c|c|c|c|c|c|}
\multicolumn{1}{|c|}{ Taxon } & $\mathbf{1}$ & $\mathbf{2}$ & $\mathbf{3}$ & $\mathbf{4}$ & $\mathbf{5}$ & $\mathbf{6}$ & $\mathbf{7}$ & $\mathbf{8}$ & $\mathbf{9}$ & $\mathbf{1 0}$ & $\mathbf{1 1}$ \\
\hline$\#$ & & & & & & & & & & & \\
\hline $\mathbf{1}$ & Doratogonus sp. (Spirostreptida) & & & & & & \\
\hline $\mathbf{2}$ & Glomeris marginata (Glomerida) & 30.5 & & & & & & & & & & \\
\hline $\mathbf{3}$ & Procyliosoma leae(Procyliosomatidae) & 30.4 & 32.5 & & & & & & & & & \\
\hline $\mathbf{4}$ & Procyliosoma spI (Procyliosomatidae) & 25.6 & 30.5 & 11.4 & & & & & & & & \\
\hline $\mathbf{5}$ & Arthrosphaera brandti (Arthrosphaeridae) & 24.7 & 31.7 & 28.8 & 27.6 & & & & & & & \\
\hline $\mathbf{6}$ & Sphaerobelum truncatum & 30.5 & 38.2 & 25.6 & 25.2 & 28.8 & & & & & & \\
\hline $\mathbf{7}$ & Zephroniidae_spIa_MalaysiaI & 30.8 & 31.9 & 25.7 & 25.5 & 26.8 & 23.5 & & & & & \\
\hline $\mathbf{8}$ & Zephroniidae_spIb_MalaysiaI & 30.8 & 31.9 & 25.7 & 25.5 & 26.8 & 23.5 & 0.0 & & & & \\
\hline $\mathbf{9}$ & Zephroniidae_spII_MalaysiaII & 30.0 & 35.5 & 25.3 & 24.8 & 27.1 & 22.8 & 22.8 & 22.8 & & & \\
\hline $\mathbf{1 0}$ & Zephronia siamensis & 32.7 & 37.7 & 28.3 & 26.8 & 28.9 & 23.5 & 22.3 & 22.3 & 23.9 & & \\
\hline $\mathbf{1 1}$ & Zephronia ovalis & 32.8 & 38.6 & 27.4 & 25.8 & 28.9 & 24.6 & 24.7 & 24.7 & 25.9 & 14.8 & \\
\hline $\mathbf{1 2}$ & Cryxus ovalis & 27.1 & 33.9 & 22.7 & 21.8 & 26.7 & 24.8 & 22.1 & 22.1 & 23.9 & 25.4 & 26.3 \\
\hline
\end{tabular}

Cryxus ovalis were added. The distances between the available species of Zephroniidae are quite high (22$26 \%$ ), with the exception of $Z$. siamensis and Z. ovalis, which show uncorrected distances of $14.8 \%$.

DESCRIPTION OF THE TREES. As expected, due to the gene choice and the apparently not too closely related taxa, little resolution is achieved in the trees (Fig. 1). All taxa of Zephroniidae group together while Z. siamensis and Z. ovalis form a well-supported $(\mathrm{MP}=100 \%, \mathrm{ML}=99 \%)$ sister-group.

\section{Redescriptions}

\section{Genus Cryxus Leach, 1814}

Leach, 1814: 407; Jeekel, 1971: 24 (list); Jeekel, 2001: 14 (list); Wesener \& VandenSpiegel, 2009: 551 (list); Wesener et al., 2010: 1188 (list). typy.
Monotypic.

A NEW DIAGNOSIS. A genus of Zephroniidae with 4- and 3-segmented posterior and anterior telopods, respectively. Tarsus of anterior telopod (Fig. 3E) curved more than $90^{\circ}$ backwards, strongly tapering towards end, together with process of podomere 2 forming a sharp-edged 'beak' (Figs 8B, C), similar to Prionobelum Verhoeff, 1924. Podomere 2 of posterior telopod slender, greatly elongated, longer than podomeres 3 and 4 combined (Fig. 3A). Tarsus of posterior telopod without any sclerotized teeth, strongly reduced in size, projecting not apically (like in all other Sphaerotheriida), but with a $90^{\circ}$ torsion (Fig. 3B), overlapping immovable process of podomere 2 . Because of torsion, apex reached not by podomere 4 , but by podomere 3 (Fig. 9A). Process of posterior telopod podomere 2 projecting farther than tibia and tarsus (Fig. 9A).

POSITION OF CRYXUS WITHIN THE SPHAEROTHERIIDA. Cryxus clearly belongs to the family 
Zephroniidae, sharing numerous apomorphies common to all members of the family [Wesener \& VandenSpiegel, 2009]. Characters uniting Cryxus with the other genera of Zephroniidae are as follows: basal plates of vulva (bursa) fused (Fig. 3H); operculum engulfing basal plate mesally and laterally (Fig. 3H); (male) antennae flattened laterally, axe-shaped (Figs 3F, 4E, F); endotergum (underside of tergites) devoid of any conical spines (Fig. 6F); stigma-carrying plates almost completely covered by coxae of walking legs and laterotergites; stigma protected not by a spine-like process of a stigma-carrying plate, but by a lateral process of coxa.

Since no phylogenetic analysis has ever been attempted in the Zephroniidae, any subfamilial or tribal association is dubious at best. We follow Jeekel's [2001] classification of the subfamily (Zephroniinae Gray, 1843, a senior synonym of Sphaeropoeinae Brölemann, 1913) and the most recent system by Mauriès [2001] for the tribes (Sphaeropoeini Brölemann, 1913, a senior synonym of Prionobelini Hoffman, 1976). Because of the close affinity in characters of Cryxus to Prionobelum Verhoeff, 1924, both these genera are placed in the same tribe.

\section{Cryxus ovalis (Linnaeus, 1758)} Figs 2-10.

Julus ovalis Linnaeus, 1758: 639.

MATERIAL EXAMINED. NEOTYPE ${ }^{\top}$ (ZMUM), Vietnam, Dong Nai Prov., Cat Tien National Park, monsoon lowland tropical forest, near a large Ficus tree, on tree trunk, 22.09.2004, leg. S. Golovatch \& A. Anichkin.

OTHER MATERIAL. $1 \sigma^{7}$ (ZMUM), same place, together with neotype; $1 \sigma^{\top}, 3 \sigma^{7} \sigma^{\top}$ (ZMUM), same locality, leaf litter, 06.2008 , leg. I. Semenyuk; 1 क (ZMUM), same locality, leaf litter, 01-02.2004, leg. A. Anichkin; $1 \sigma^{\top}$ (ZMUM), same locality, leaf litter, 01.2004, leg. A. Evsyunin; $10 \bigcirc^{\top} \sigma^{\top}, 6$ O+ , 9 juv. (ZMUM), same locality, near a large Ficus tree, leaf litter, 27.05.2008, leg. I. Semenyuk; 1 O $^{7}$ (ZFMK Myr 0824*), 1 ( Vietnam, Dong Nai Province, Cat Tien National Park, 09.2005. leg. A. Anichkin.

COMMENTS. The type specimens of Julus ovalis could not be traced and are most likely lost. Therefore, a neotype was selected among recently collected material.

ORIGINAL DIAGNOSIS AND DESCRIPTION. "Pedibus utrinque XX. [...]. Segmenta corporis oblongo-ovalis 10 , praeter thoracis \& caudae." [Linnaeus, 1758: 639].

A NEW DIAGNOSIS. See the above redescription of Cryxus for characters separating C. ovalis from all other known giant pill-millipede species.

REDESCRIPTION. Measurements: neotype ca 16 $\mathrm{mm}$ long, $6.5 \mathrm{~mm}$ wide, $4.5 \mathrm{~mm}$ high at tergite 2, 4.0 $\mathrm{mm}$ high at anal shield. Other specimens ca 11-18 $\left(\sigma^{7} \sigma^{7}\right)$ or 14-18.5 mm (ㅇ); maximum width (at tergum 2), 5.0-9.0 $\left(\sigma^{7} \sigma^{7}\right)$ or 6.5-9.0 mm (oo); height at tergum 2, 3.5-5.5 $\left(\sigma^{7} \sigma^{7}\right)$ or 4.5-6.0 mm (+o); height at anal shield, 2.5-4.7 $\left(\sigma^{7} \sigma^{7}\right)$ or 4.0-5.0 mm (우).

Body small, relatively slender, glabrous, dull.

Coloration: anterior half of head light brown, posterior half dark green, collum light brown (Fig. 2A).
Thoracic shield (tergite 2) and tergites 3-12, as well as anal shield in front $3 / 4$ extent dark green, posteriormost quarter light brown (Fig. 2B). Antennae brown, legs with a brown-green pattern.

Head typical of the order. Ocellaria with ca 70 ocelli and a single isolated ocellus located inside antennal groove (Fig. 4A). Tömösváry's organ not separated from ocellaria, much smaller in diameter than an individual ocellus (Fig. 4B), inside with conical processes (Fig. 4C). Posterior margin of head without field of small setae.

Antennae: length of antennomeres $1>2=3=4=5<<6$, last antennomere almost as large as three basal ones combined (Fig. 4E). First antennomere without a groove, but with rounded, sclerotized teeth (Fig. 4E). Antennomeres 1-5 much wider apically than basally (Fig. 4F). Antennomere 6 flattened laterally and twice as wide apically as basally (Figs 4E, F), towards disc with 1-2 rows of sensilla basiconica. Disc bearing 25-28 $(+)$ or 33-35 $\left(\mathrm{O}^{7}\right)$ sensory cones (Figs 4E, F). Antennomeres 1-5 abundantly setose, antennomere 6 more densely so, with setae of varying lengths, longest ones surpassing combined length of two basal antennomeres.

Mandibles with a single external tooth, a 3-combed inner tooth, five rows of pectinate lamellae (Fig. 5E). Intermediate area consisting of several rows of large spines (Fig. 5E). Condylus with a prominent 'step' and a single long seta directed towards apex (Fig. 5E).

Gnathochilarium: ventral surface covered with numerous setae (Fig. 4D). Palpi with a single field of numerous sensory cones (Fig. 5A). Reduced lateral palpi consisting of a 'bump' with 3 or 4 sensory cones (Fig. 5B). Centrally located pads with a single field of numerous papillae (Fig. 5C), each papilla surrounded by cuticular scales (Fig. 5D). Hypopharynx consisting of a strongly sclerotized area with a single triangular tooth, surrounded laterally by a single dense row of sclerotized spines (Fig. 5A). Epipharynx with a single, centrally located sclerotized plate, apically with a single large tooth (Fig. 5F). Sclerotized plate surrounded by a single row of short conical spines, laterally and apically with several rows of longer spines (Fig. 5F). Basally on each side with a field of small scale-like spines with a very wide base (Fig. 5G).

Collum (tergite 1): anterior and posterior margins with a few long setae, central part clothed with sparse, isolated, shorter setae.

Thoracic shield (tergite 2) glabrous except for lateral grooves carrying a few long setae. Grooves shallow, but margin of groove with 2 or 3 elevated ridges. A single stria running dorsally along anterior margin.

Tergites 3-12: surface generally glabrous and dull. Body not much higher posteriorly than anteriorly. Starting from tergite 6, paratergite tips strongly projecting posteriorly. Anterior margin with a single row of large, round, sclerotized grains followed by 2 or 3 rows of smaller, round, cuticular spots behind (Figs $6 \mathrm{~A}, \mathrm{~B})$. Towards paratergite, the latter replaced by striae. Tergal surface glabrous (Fig. 6B), except for a 


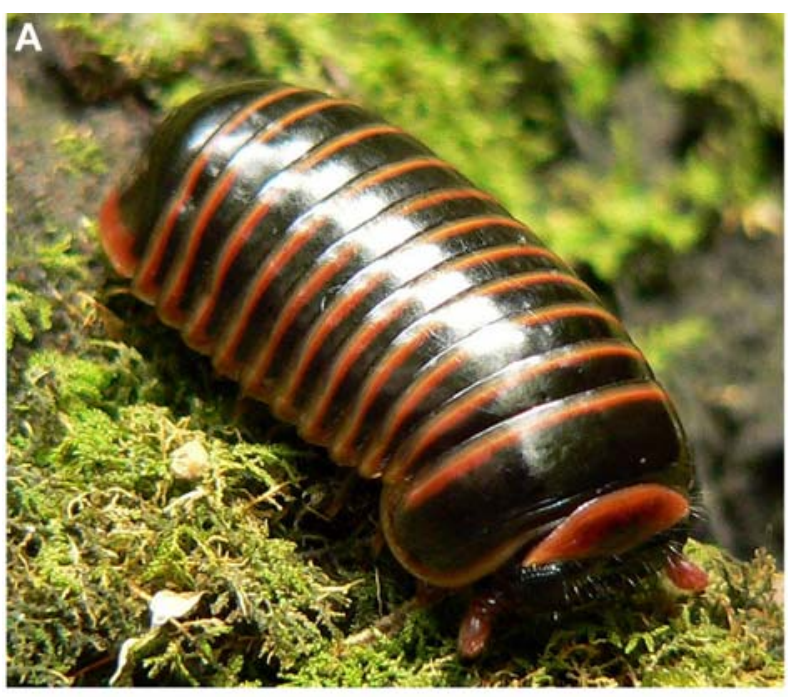

C

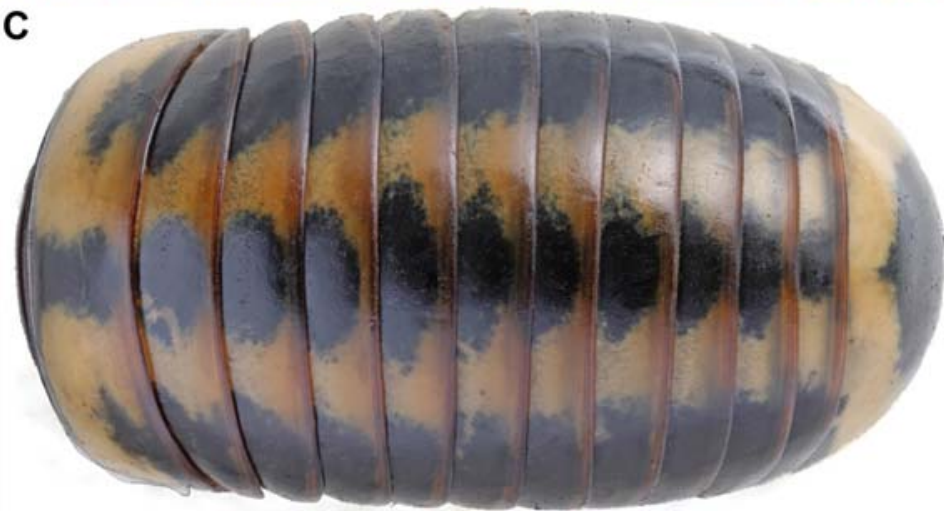

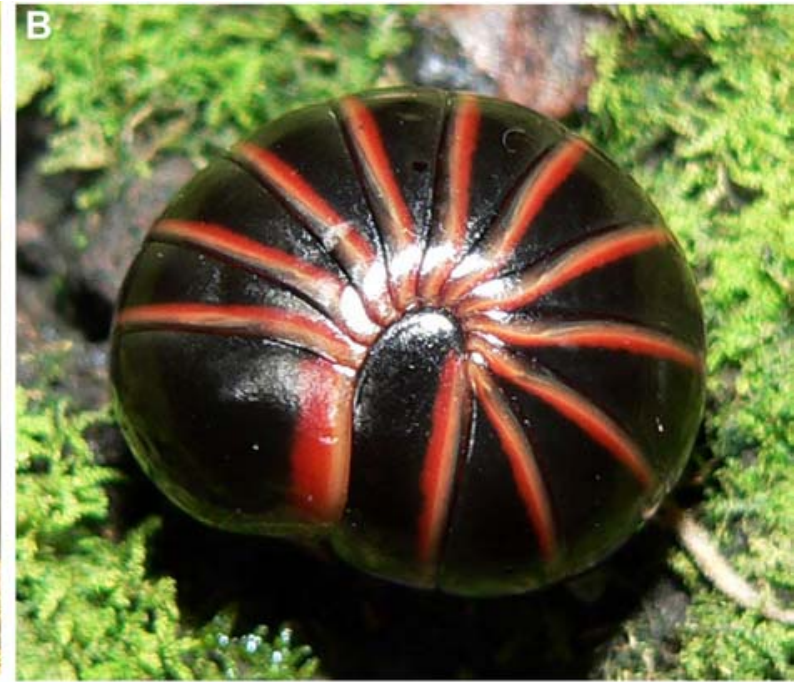

D

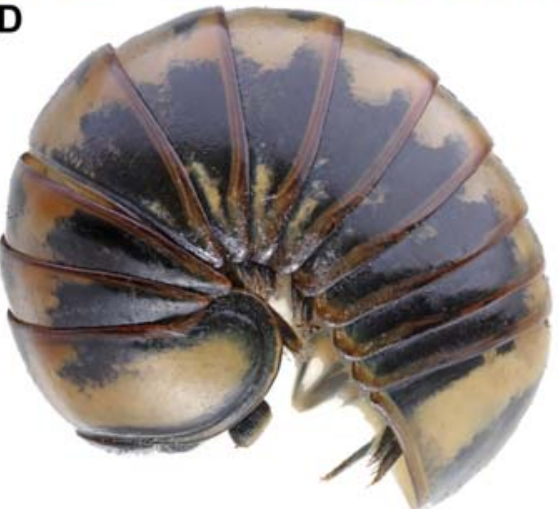

Fig. 2. Habitus, Cryxus ovalis (Linnaeus, 1758) (A, B) and Zephronia ovalis Gray, 1832 (C, D). Photographed not to scale. Рис. 2. Габитус, Cryxus ovalis (Linnaeus, 1758) (А, В) и Zephronia ovalis Gray, 1832 (C, D). Сфотографировано без масштаба.

densely setose paratergite depression, beset with minute, shallow pits (Fig. 6C). Surface of posterior margin (limbus) well-rounded, without peculiarities (Fig. 6D). Underside of each paratergite with a black, sclerotized, locking carina (Fig. 6E).

Endotergum (underside of posterior margin of tergite): a single row of marginal bristles reaching $2 / 3$ of distance to edge (Fig. 6F). Bristles smooth, placed at regular intervals between one another. Marginal ridge well-rounded, at inner margin with a single row of very large cuticular impressions (Fig. 6F). Inner area without any spines, almost glabrous (Fig. 6F).

Anal shield glabrous, in ${ }_{+}$well-rounded, in $\sigma^{7}$ bellshaped with a strongly recessed posterior margin. Tergite 13 completely fused with anal shield, neither suture nor indentation visible. Underside carrying one long, black, locking carina located close to lateral margin.

Legs: Legs 1 and 2 with neither coxal lobe nor apical spine. Tarsi 1 with 6 or 7, 2 with 4-7, 3 with $6-8$, and midbody tarsi with 9-12 ventral spines, all located in distal half (Fig. 3G). Legs 3-21 with a single apical spine on tarsi and a well-rounded coxal lobe. In leg 9, femur
1.8, tarsus 4.7 times longer than wide. Femur on posterior side on legs 1-21 with one long ridge (Fig. 3G).

Stigmatic plates: first stigmatic plate rounded, curved towards coxa, stigma opening located close to inner margin. Second plate larger, a lower area separating stigma opening from inner margin (Figs 7A, C). Stigmatic plates 3-21 narrow, overlapped by latero-tergites, stigma opening protected by a coxal process.

Latero-tergites large, well-rounded, clothed with numerous long setae. Marginal rim strongly developed, especially so anteriorly (Fig. 7D). First latero-tergite elongated into a strongly tapering process (Fig. 7D).

Vulva: both basal plates (= bursa) fused, operculum surrounding bursa only apically. Operculum pointed apically, protruding into a well-rounded tip at inner margin, protruding distally above coxa up to anterior third of prefemur (Fig. 3H).

Subanal plate small, without ribs, almost completely divided apically into two separate halves, each elongated into a well-rounded lobe.

Male gonopore located mesally (Fig. 7A), covered with a basally sclerotized, apically membranous plate 


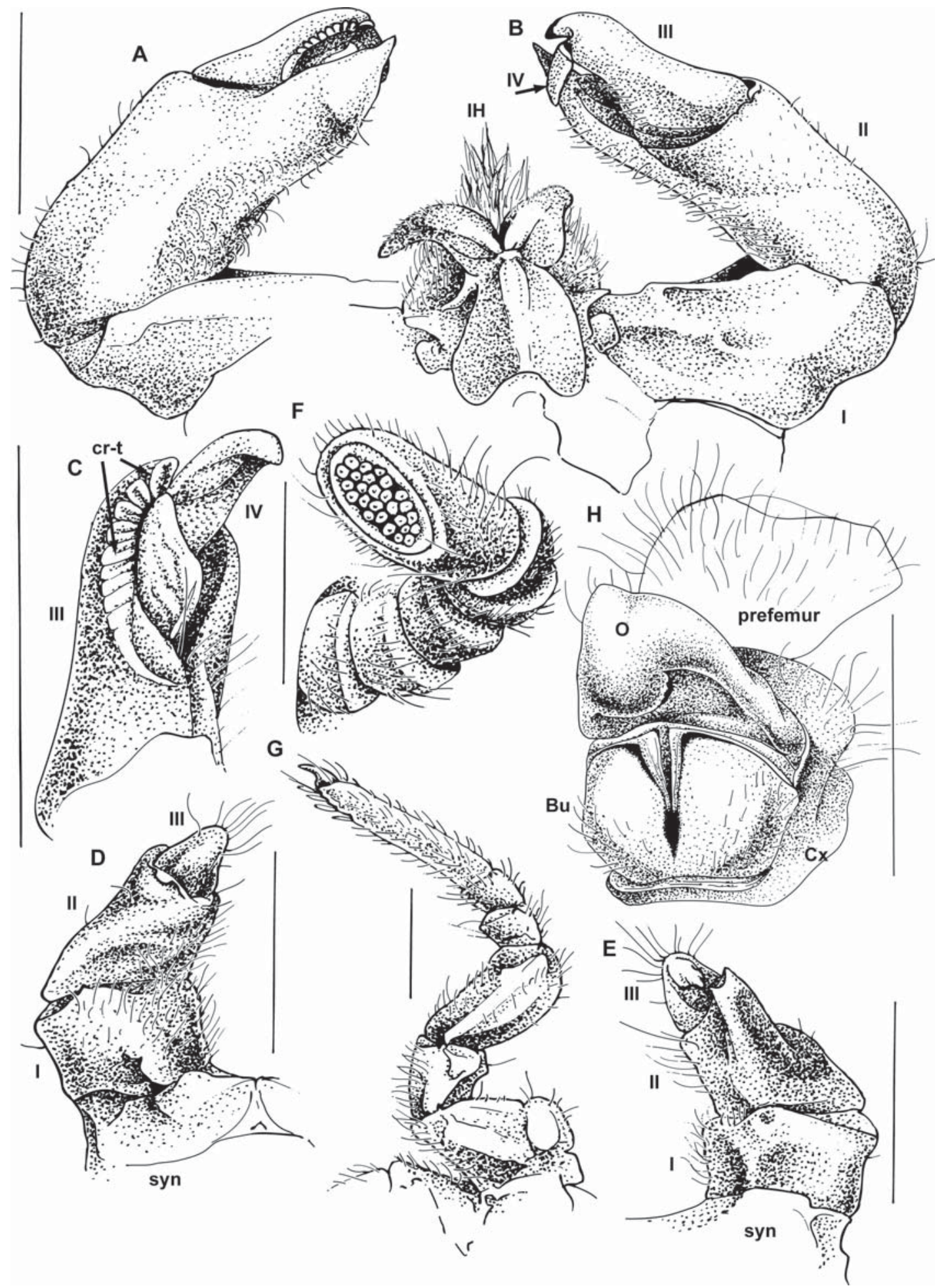

Fig. 3. Cryxus ovalis (Linnaeus, 1758) (ZFMK MYR 0824 \& 0831): A — posterior telopod, caudal view; B — posterior telopod with inner horns, front view; C - posterior telopod, podomeres $3 \& 4$; D - left half of anterior telopod, front view; E - left half of anterior telopod, caudal view; F - left antenna; $\mathrm{G}$ - left leg 10, caudal view; $\mathrm{H}$ - left coxa 2 and prefemur 2 with vulva. Abbreviations: Bu bursa; cr-t - crenulated teeth; $\mathrm{Cx}-$ coxa; $\mathrm{IH}$ - inner horns; $\mathrm{O}$ - operculum; syn - syncoxite; Roman numerals - number of podomere. Scale bars $-1.0 \mathrm{~mm}$.

Pис. 3. Cryxus ovalis (Linnaeus, 1758) (ZFMK MYR 0824 \& 0831): А - задний телопод, сзади; В - задний телопод с внутренними рогами, спереди; C - задний телопод, сегменты 3 и 4; D - левая половина переднего телопода, спереди; Е — левая половина переднего телопода, сзади; F - левая антенна; $\mathrm{G}$ - левая нога 10, сзади; $\mathrm{H}$ - левые кокса 2 и префемур 2 с вульвой. Сокращения: $\mathrm{Bu}$ - сумка; $\mathrm{cr-t}$ - мелкозазубренные зубы; $\mathrm{Cx}$ - кокса; $\mathrm{IH}$ - внутрениие рога; $\mathrm{O}$ - крышечка; syn — синкоксит; римские цифры - номер сегмента. Масштаб: 1,0 мм. 

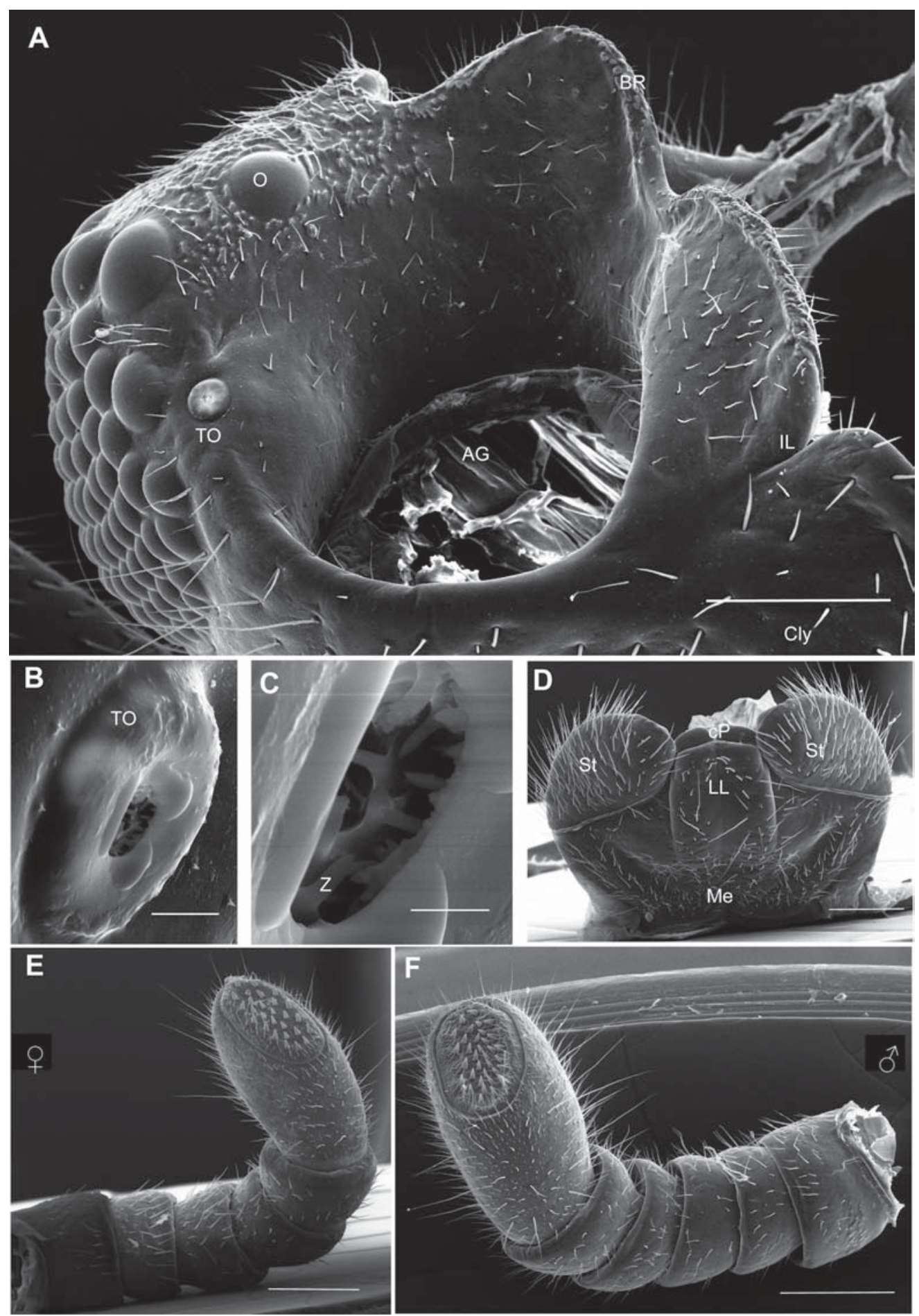

Fig. 4. Cryxus ovalis (Linnaeus, 1758) (ZFMK MYR $0824 \&$ 0831): A $-\bigcirc^{7}$ head, lateral view into antennal groove; B $-O^{7}$ organ of Tömösváry, overview; $\mathrm{C}$ - organ of Tömosváry, inner view; D - $\sigma^{2}$ gnathochilarium, ventral view; $\mathrm{E}-q+$ left antenna; $\mathrm{F}-\mathrm{O}^{7}$ right antenna. Abbreviations: AG - antennal groove; BR — brim of head; Cly — clypeus; $\mathrm{cP}$ - centrally located pads (rudimentary median palpi); IL — incisura lateralis; LL — lamellae linguales; Me — mentum; O — isolated ocellus; $\mathrm{St}$ — stipes; TO — organ of Tömösváry; $\mathrm{Z}$ - 'cone' inside organ of Tömösváry. Scale bars: A $-0.4 \mathrm{~mm}$; B $-0.02 \mathrm{~mm}$; C $-0.006 \mathrm{~mm}$; D $-0.4 \mathrm{~mm}$; E \& F $-0.5 \mathrm{~mm}$.

Рис. 4. Cryxus ovalis (Linnaeus, 1758) (ZFMK MYR 0824 \& 0831): А - голова О7, вид сбоку внутрь антеннального желобка;

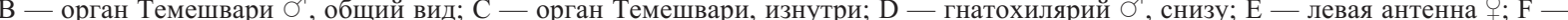
правая антенна $\mathrm{O}^{7}$.Сокращения: AG - антеннальный желобок; $\mathrm{BR}$ - край головы; Сly — наличник; сP — центрально расположенные подушки (рудиментарные медиальные щупики); IL - боковой вырез; LL - язычковые пластины; Me - ментум; O изолированный глазок; St — стволики; ТО — орган Темешвари; Z — 'конус' внутри органа Темешвари. Масштаб: А — 0,4 мм; В - 0,02 мм; C-0,006 мм; D-0,4 мм; E-F - 0,5 мм. 


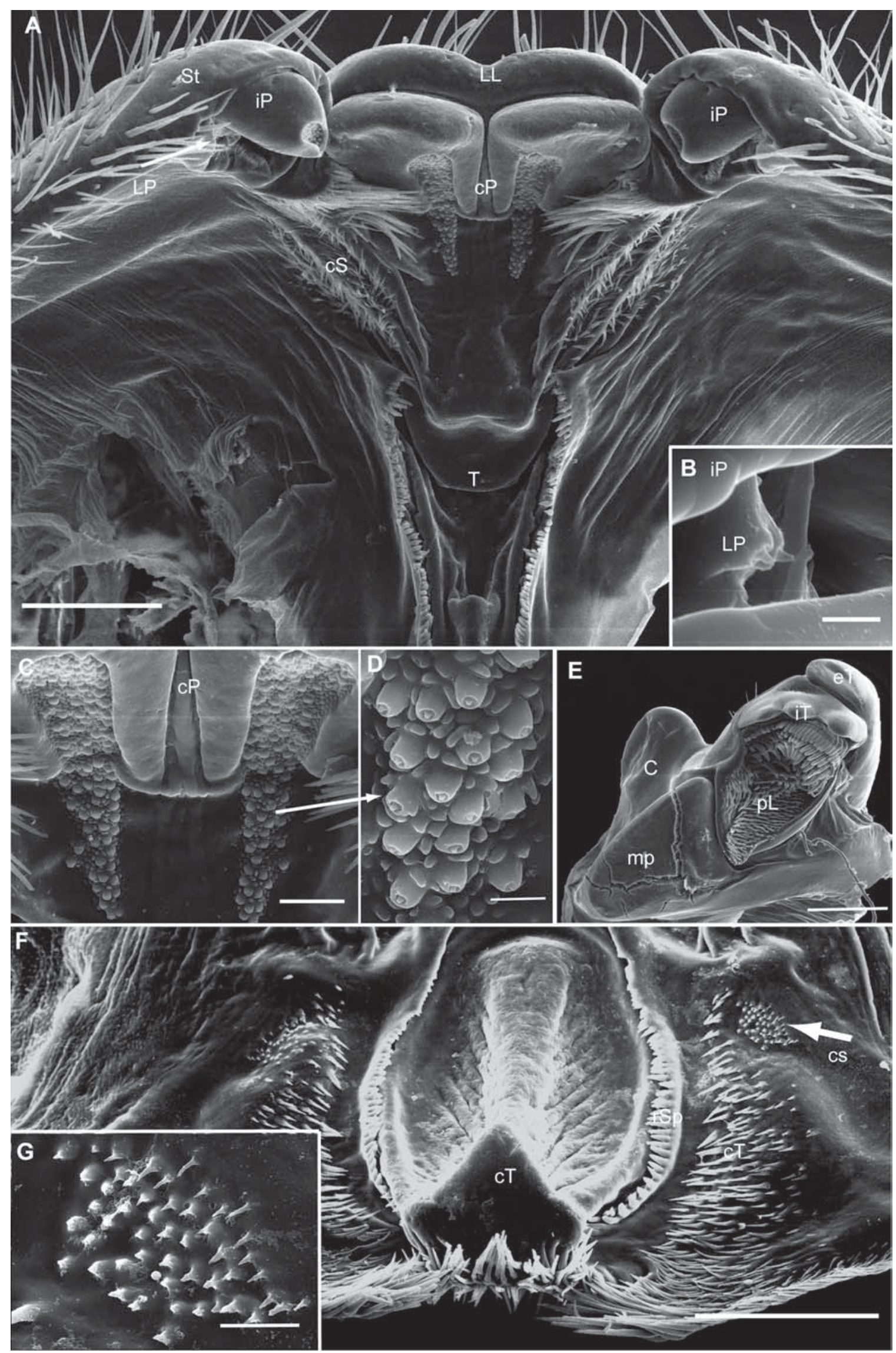


(Fig. 7B). Sclerotized part of plate carrying numerous long setae (Fig. 7B). Distal to gonopore, a smoother, darker, more strongly sclerotized area.

Anterior telopods with three podomeres beyond syncoxite (Fig. 3D). Syncoxite glabrous except for a few long setae, divided into two halves by a weakly sclerotized white area (Fig. 3D). First podomere rectangular, in anterior view with numerous long setae, especially in meso-apical part (Fig. 8A), posterior side glabrous (Fig. 3E). Second podomere tapering apically, surface with a few hairs except at mesal margin (Fig. 8A), posterior side with a flat, ridge-like process (Fig. $8 \mathrm{~B})$. The podomere laterally to process glabrous, mesally with a field of longer setae (Fig. 8C). Basally, as well as on ridge of process with sensory pits. Second podomere devoid of any sclerotized teeth, spines or spots. Process of second podomere and apical part of third podomere forming a 'beak' or pincer (Fig. 8B). Third podomere bent backwards (Fig. 8C), with a tapering apical part whose tip touching the process of second podomere (Fig. 8C). Third podomere apically in anterior view covered with long setae (Fig. 8A), in posterior view with a swollen area carrying at least one spine (Fig. 8C).

Posterior telopods elongated and slender, with four podomeres distal to syncoxite (Fig. 3B). Syncoxite consisting of inner lobes and inner horns (Fig. 10A). Inner lobes densely pilose, tips projecting between the inner horns (Fig. 10B). Inner horns consisting of a basal, glabrous half and two basally touching, but completely separated and projecting horns; both areas divided by a suture (Fig. 10A). Horns slender, tapering and diverging apically; basally with a few, apically with numerous, setae. Tip of each horn membranous, scoop-shaped, covered with 2 or 3 conspicuously branched setae (Fig. 10C).

First podomere strongly elongated, almost 2 times longer than wide, carrying a few setae (Fig. 3B). Second podomere also elongated, discarding immovable finger 1.7-1.8 times longer than wide (Figs 9A, 10D). Mesal margin, especially basally, with a dense field of long setae (Fig. 9A), anterior side with numerous long setae (Fig. 9A), posterior side glabrous (Fig. 10D).

Process of second podomere strongly tapering towards tip, apical part slightly bent distad towards third podomere (Fig. 9A). Process long, clearly overreaching third podomere in length (Fig. 3B). Apical- most part of inner margin with 3 or 4 rows of sclerotized elongated spots (Fig. 9B), especially on posterior side (Fig. 10D).

Third podomere stout, slightly tapering towards tip (Fig. 9A). A few longer setae on anterior side (Fig. 9A) of third podomere, both sides sparsely covered with minute sensorial pits (Fig. 9D). Mesal margin with a membranous ridge, one spine and approximately 11 large, sclerotized, crenulated teeth (Figs 9C, D). Fourth podomere not located apically, but mesally on third podomere (Figs 3C, 9D, 10D).

Fourth podomere rudimentary, short and conical, 3 times longer than wide, with a well-rounded tip (Fig. 9D). Anterior side of fourth podomere with minute sensorial pits, inner margin hollowed-out, carrying a single spine (Fig. 10D).

REMARKS. The above description fits the available original ones [Linnaeus 1758, 1759] completely, including even the presence of only one spine behind the claw on the legs.

\section{Genus Zephronia Gray, 1832}

Zephronia Gray, 1832: 796; Gervais, 1837: 42; Newport, 1844: 265; Gervais, 1844: 61; Gervais, 1847: 75; Butler, 1873: 178; Pocock, 1894: 326; Pocock, 1895: 413; Silvestri, 1896b: 205; Pocock, 1899: 270; Flower, 1901: 7; Attems, 1914: 142, 144; Attems, 1926: 120; Attems, 1935: 129; Attems, 1936: 153; Attems, 1943: 63; Attems, 1953: 155; Jeekel, 1971: 29; Jeekel, 1974: 46; Hoffman, 1976: 120; Hoffman, 1980: 64; Jeekel, 2001: 17; Wesener \& VandenSpiegel, 2009: 551; Wesener et al., 2010: 1188.

Type species: Zephronia ovalis Gray, 1832, by monotypy.

COMMENTS. According to the latest checklist [Jeekel, 2001], Zephronia includes 37 species or subspecies. However, since the genus was not properly defined, based on morphological characters, while numerous of the species in the family Zephroniidae are only known from their first descriptions, several more steps, especially taxonomic revisions, are needed to get a more complete picture of the diversity and distribution of Zephronia. The redescription of the insufficiently described type species, Z. ovalis, can here be viewed as the first step in that direction.

A NEW DIAGNOSIS. A genus of Zephroniidae with 4-segmented posterior (Figs 11A, B) and anterior telopods (Figs 11C, D). Immovable finger of posterior telopod relatively slender, apically tapering, with a

Fig. 5. Cryxus ovalis (Linnaeus, 1758), Ơ (ZFMK MYR 0824): A — gnathochilarium, dorsal view; B - rudimentary lateral palpus; C - endochilarium, central pads, overview; D - sensory cones of central pads; E - left mandible, mesal view; F — epipharynx, overview; G - epipharynx, cuticular scales. Abbreviations: C - condylus; $\mathrm{cP}$ - central pads; cS — combed spines; cs - cuticular scales; cT — central tooth; eT — external tooth; iP — inner palpus; iT — inner teeth; LL — lamellae linguales; LP — rudimentary lateral palpus; $\mathrm{mp}$ - molar plate; $\mathrm{pL}$ - pectinate lamellae; $\mathrm{rSp}$ - row of spines; $\mathrm{St}$ — stipes. Scale bars: A \& F - $0.2 \mathrm{~mm}$; B - $0.005 \mathrm{~mm}$; C $0.1 \mathrm{~mm} ; \mathrm{D}-0.01 \mathrm{~mm} ; \mathrm{E}-0.3 \mathrm{~mm} ; \mathrm{G}-0.02 \mathrm{~mm}$.

Рис. 5. Cryxus ovalis (Linnaeus, 1758), О7 (ZFMK MYR 0824): A — гнатохилярий, сверху; В — рудиментарный боковой щупик; C - эндохилярий, центральные подушки, общий вид; D - сенсорные конусы центральных подушек; Е - левая мандибула, изнутри; F — эпифаринкс, общий вид; G — эпифаринкс, кутикулярные чешуйки. Сокращения: C — мыщелок; сP — центральные подушки; cS — гребенчатые шипы; cs — кутикулярные чешуйки; cT — центральный зуб; еT — наружный зуб; iP — внутренний щупик; iT — внутренние зубы; LL — язычковые пластины; LP — рудиментарный боковой щупик; $\mathrm{mp}$ - молярная пластина; $\mathrm{pL}$ -

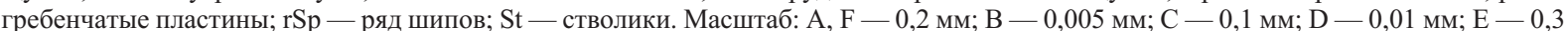
мм; G - 0,02 мм. 


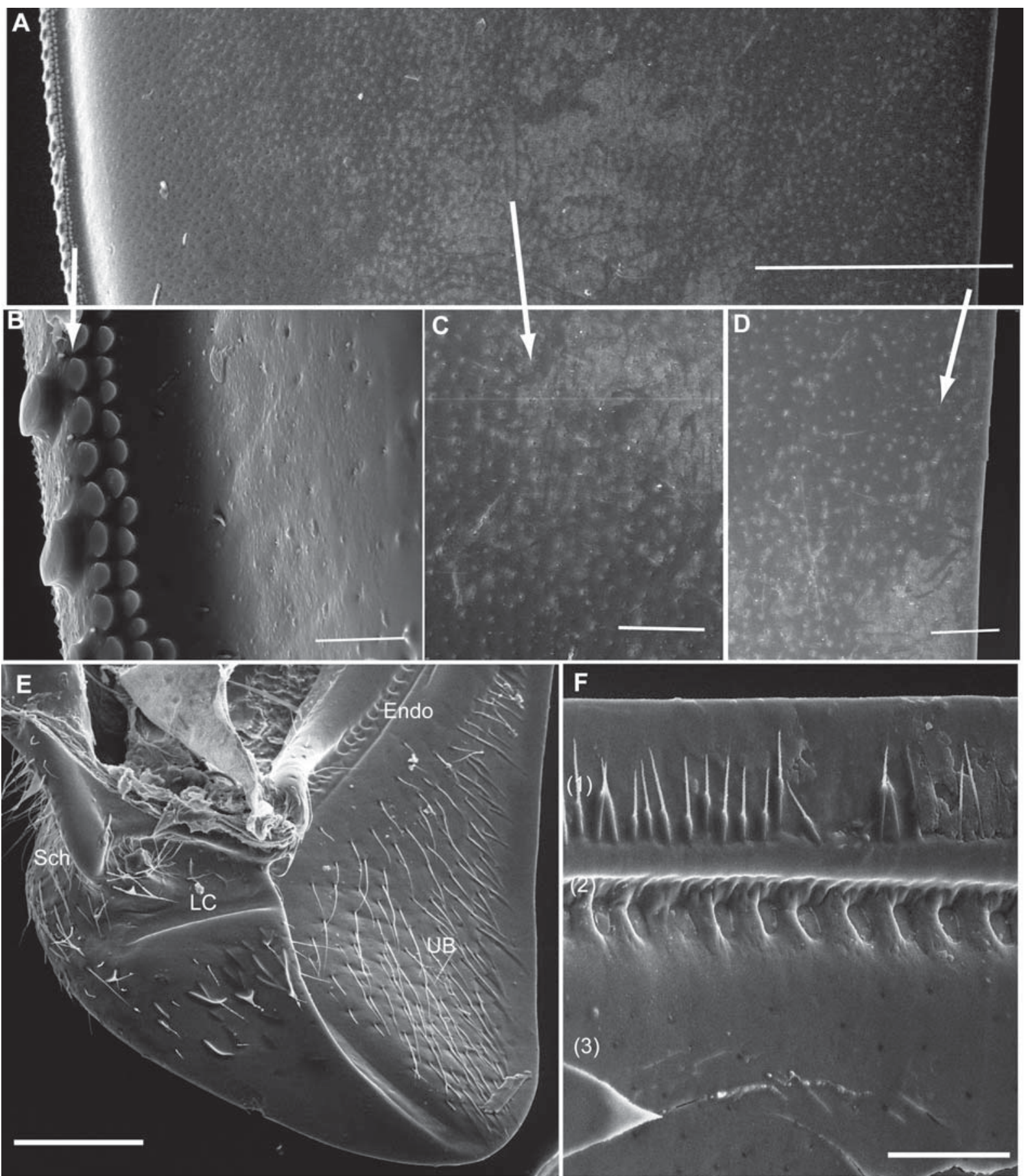

Fig. 6. Cryxus ovalis (Linnaeus, 1758), O' (ZFMK MYR 0824), tergite 6: A - dorsal overview; B - anterior margin; C - medial part; D - posterior margin; E - paratergite, underside; F — endotergum. Abbreviations: (1) - outer area with a row of setae; (2) middle area with a crest and cuticular patterns; (3) - inner area; Endo - endotergum; LC — locking carina; Sch — schisma of tergites; UB - 'Unterblatt', section of tergite that is pushed above following tergite. Scale bars: A \& F $-0.5 \mathrm{~mm}$; B $-0.03 \mathrm{~mm}$; C \& E -0.1 $\mathrm{mm} ; \mathrm{D}-0.05 \mathrm{~mm}$.

Pис. 6. Cryxus ovalis (Linnaeus, 1758), O' (ZFMK MYR 0824), тергит 6: A - общий вид сверху; В — передний край; C средняя часть; D - задний край; Е — паратергит, снизу; F - эндотергум.Сокращения: (1) - наружная часть с рядом щетинок; (2) - средняя часть с ребром м кутикулярным рисунком; (3) - внутренняя часть; Endo - эндотергум; LC — замыкающий гребень; Sch - схизма тергитов; UB — ‘нижний листок’, отдел тергита, вытолкнутого поверх следующего тергита. Масштаб: A, F - 0,5 мм; B - 0,03 мм; C, E-0,1 мм; D - 0,05 мм. 

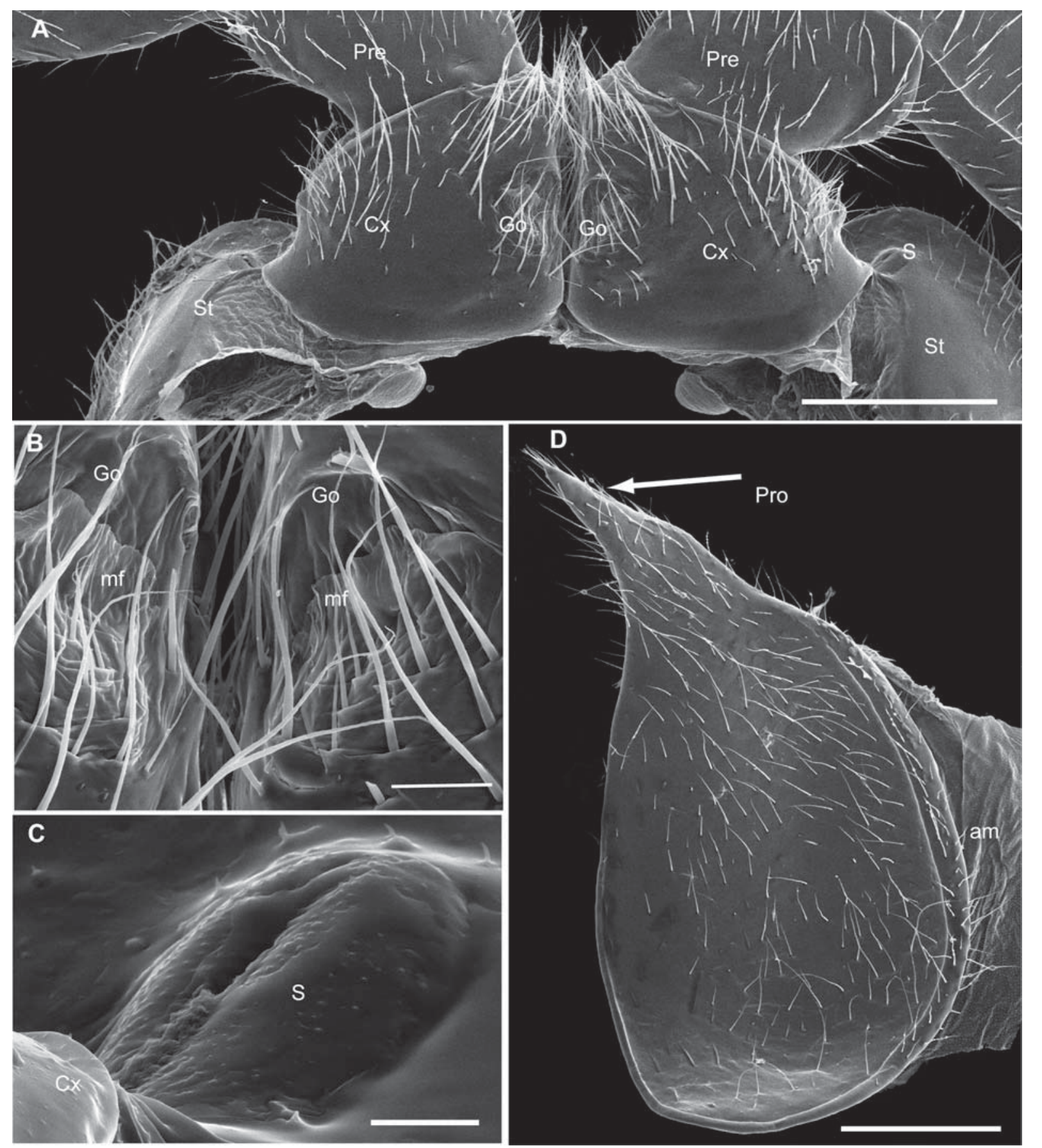

Fig. 7. Cryxus ovalis (Linnaeus, 1758), $O^{7}$ (ZFMK MYR 0824): A — coxae, prefemur and stigma-carrying plate 2; B - male gonopore, detail; C - stigma opening, stigma-carrying plate 2; D - latero-tergite 1. Abbreviations: am - anterior margin of laterotergite; $\mathrm{Cx}$ - coxa; Go — gonopore; $\mathrm{mf}$ - membranous folds; Pre — prefemur; Pro — lateral process; $\mathrm{S}$ — stigma; St — stigma-carrying plate. Scale bars: A $-0.6 \mathrm{~mm}$; B $-0.08 \mathrm{~mm}$; C $-0.03 \mathrm{~mm}$; D $-0.5 \mathrm{~mm}$.

Рис. 7. Cryxus ovalis (Linnaeus, 1758), О7 (ZFMK MYR 0824): A - коксы, префемур и несущая дыхальце пластина 2; В гонопор, увеличено; C - отверстие дыхальца, несущая дыхальце пластина 2; D - латеротергит 1. Сокращения: ат — передний край латеротергита; $\mathrm{Cx}$ - кокса; Go — гонопор; $\mathrm{mf}$ - мембранные складки; Pre — префемур; Рro - боковой отросток; $\mathrm{S}$ дыхальце; St - несущая дыхальце пластина. Масштаб: A - 0,6 мм; В - 0,08 мм; C - 0,03 мм; D - 0,5 мм. 

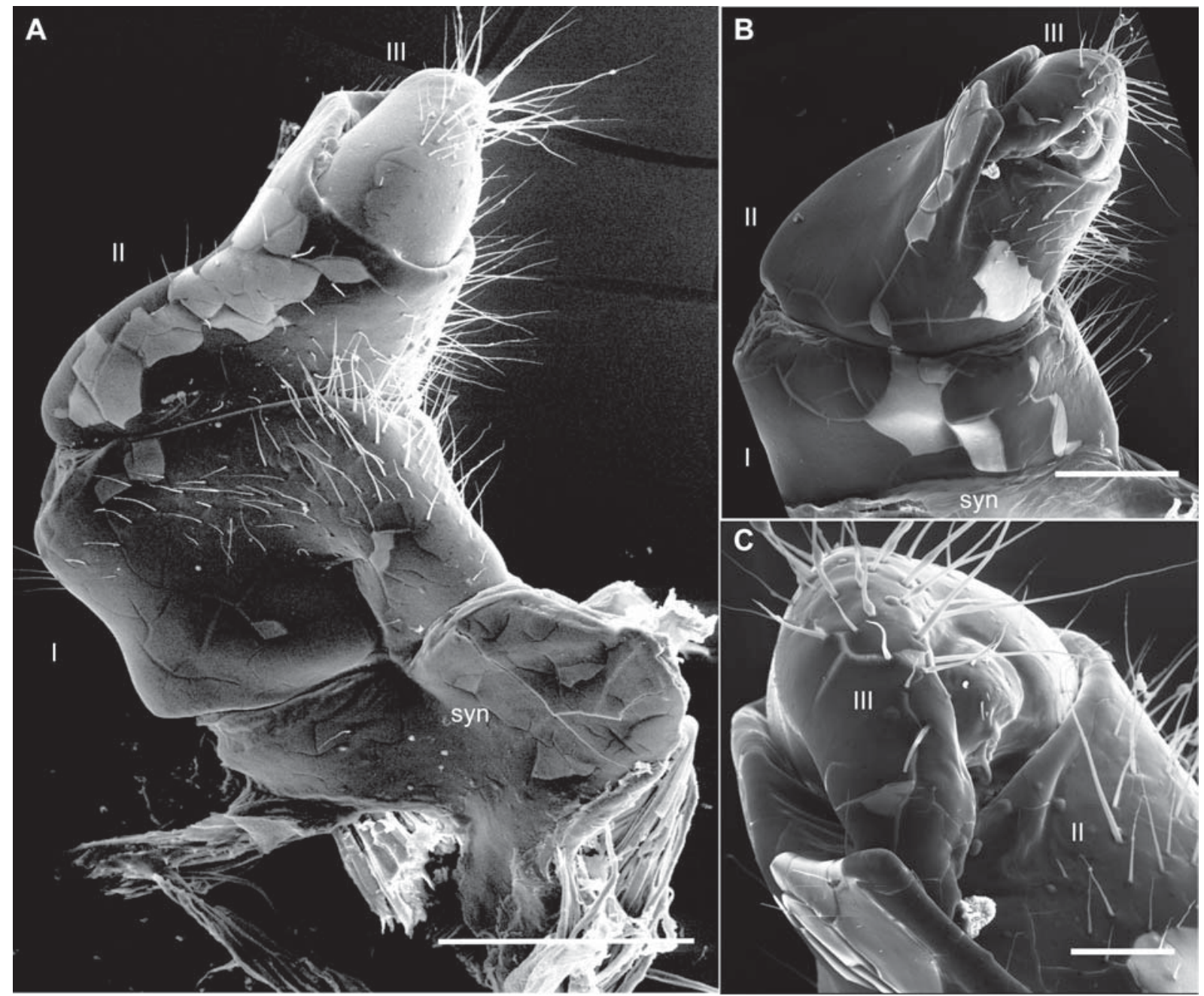

Fig. 8. Cryxus ovalis (Linnaeus, 1758), O (ZFMK MYR 0824), left anterior telopod: A - overview; B - posterior view; C - last two podomeres, posterior view, detail. Abbreviations: syn - syncoxite; Roman numerals — number of podomere. Scale bars: A — 0.5 $\mathrm{mm} ; \mathrm{B}-0.3 \mathrm{~mm} ; \mathrm{C}-0.1 \mathrm{~mm}$.

Рис. 8. Cryxus ovalis (Linnaeus, 1758), О7 (ZFMK MYR 0824), левый передний телопод: А - общий вид; В - сзади; С — два последних членика, сзади крупным планом. Сокращения: syn - синкоксит; римские цифры - номер членика. Масштаб: А - 0,5 мм; В - 0,3 мм; C-0,1 мм.

membranous ledge elevated into two large membranous lobes (Fig. 11A). Third podomere of posterior telopod much larger than podomere 4 , the former with a row of round, crenulated teeth and a large membranous ledge (Fig. 11B). Chela of anterior telopods formed by process of second podomere and podomeres 3 and 4 (Fig. 11C). Differs from Sphaeropoeus, the only genus with similar posterior telopods, in the absence of a peculiarly shaped process on podomere 3 of the anterior telopods. Tarsus of walking legs often (but not in all species) with more than one apical spine (Fig. 13G).

POSITION OF ZEPHRONIA WITHIN THE ZEPHRONIIDAE. Since Zephronia is the type genus of the family, as well as of the subfamily Zephroniinae Gray, 1843 , its position is already predetermined. According to Jeekel [2001], Zephronia is in the tribe Zephroniini together with numerous other genera such as Bothrobelum Verhoeff, 1924, Cryxus, Indosphaera Attems, 1936,
Kophosphaera Attems, 1936, Leptotelopus Silvestri, 1897, Prionobelum and Sphaerobelum, while Mauriès follows a different approach, keeping a separate monogeneric tribe Indosphaerini Hoffman, 1976, and grouping most of the other genera in the tribe Sphaeropoeini [Mauriès, 2001]. Since no phylogenetic analysis of the Zephroniidae has heretofore been conducted whilst neither of the authors [Jeekel, 2001, Mauriès, 2001] has provided characters to justify their re-arrangement of the genera in the family, any groupings of the genera in the family are tentative at best.

\section{Zephronia ovalis Gray, 1832}

Figs 2C, D; 11-13.

Zephronia ovalis Gray, 1832: 796, pi. 135 fig. 5, 5a-5c (1);

Zephronia ovalis - Gervais, 1837: 42 (list);

Zephronia ovalis - Newport, 1844: 264 (new locality); 

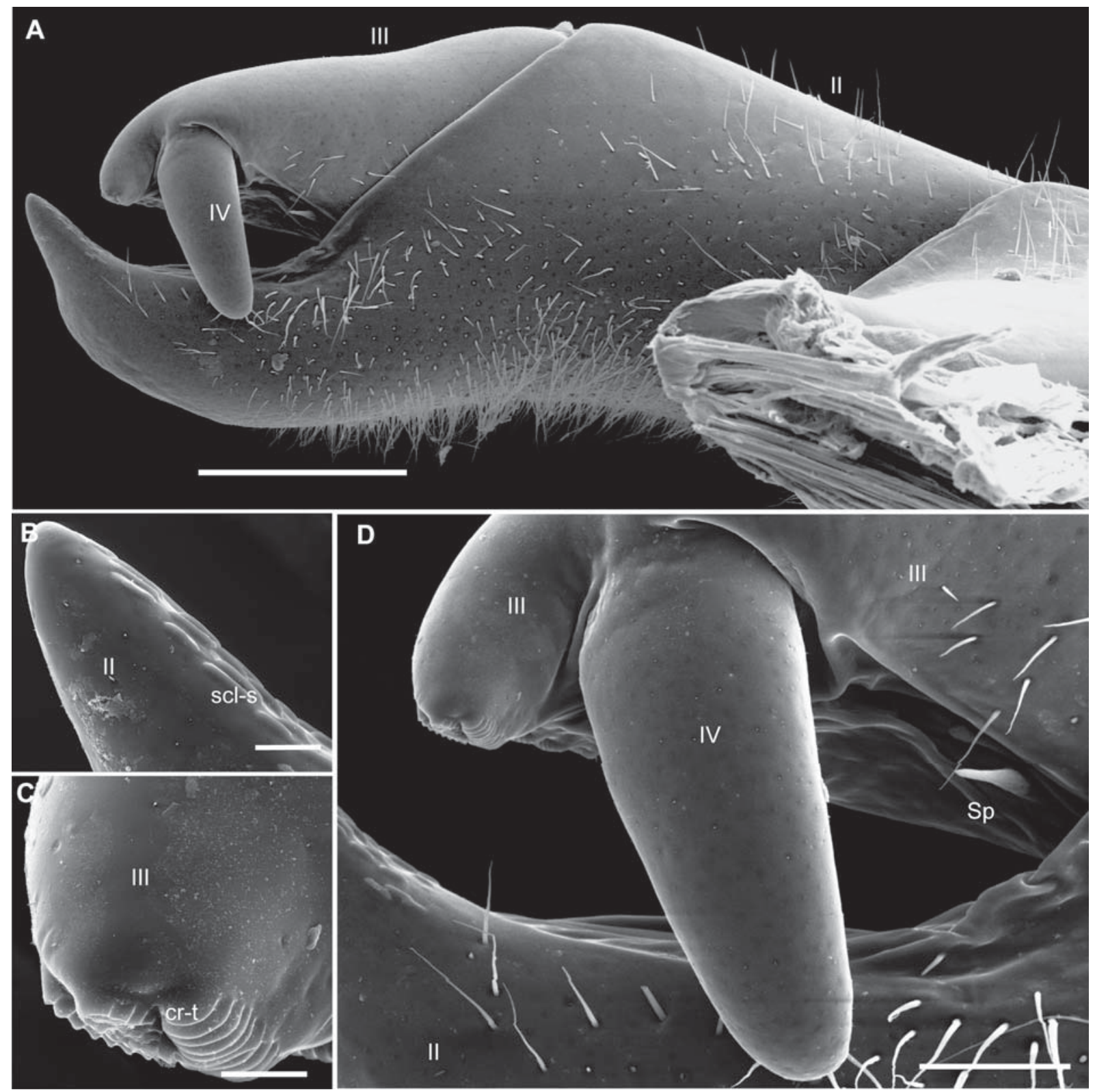

Fig. 9. Cryxus ovalis (Linnaeus, 1758), O' (ZFMK MYR 0824), right posterior telopod: A — anterior view; B — process of podomere 2, detail; C - crenulated teeth in apical part of podomere 3; D - podomere 4. Abbreviations: cr-T — crenulated teeth; scl-s — sclerotized spots; Sp - spine; Roman numerals - number of podomere. Scale bars: A $-0.4 \mathrm{~mm}$; B $-0.03 \mathrm{~mm}$; C $-0.02 \mathrm{~mm}$; D $-0.1 \mathrm{~mm}$.

Рис. 9. Cryxus ovalis (Linnaeus, 1758), O (ZFMK MYR 0824), правый передний телопод: А — спереди; В — отросток членика 2, увеличено; C - мелкозазубренные зубы в вершинной части членика 3; D - членик 4. Сокращения: cr-T — селкозазубренные зубы; scl-s — склеротизированные пятна; Sp — шип; римские цифры — номер членика. Масштаб: A — 0,4 мм; B — 0,03 мм; C 0,02 мм; D - 0,1 мм.

Sphaerotherium ovale - C.L. Koch, 1847: 99 (list);

Zephronia ovalis - Butler, 1873: 180;

Zephronia ovalis - Olliff, 1882: 30, fig. 1;

Zephronia ovalis - Attems, 1914: 146 (list).

Zephronia ovalis - Jeekel, 2001: 20 (list, comments)

MATERIAL EXAMINED. NEOTYPE $\sigma^{7}$ (ZMUM), Vietnam, Dong Nai Prov., Cat Tien National Park, monsoon lowland tropica forest, near a large Ficus tree, leaf litter, 27.05.2008, leg. I. Semenyuk.

OTHER MATERIAL: $1 \sigma^{7}$ (ZFMK MYR0825), 1 ( (ZFMK MYR0832*), Vietnam, Dong Nai Province, Cat Tien National
Park, forest, coll. I. Semenyuk, 24.06.2011. DNA was extracted from muscle tissue of this specimen; 1 (ZMUM), same locality, Lagerstroemia plot, litter, 8.07.2011, leg. A.V. Tiunov.

COMMENTS. Already Jeekel stated [2001: 21] "The identity of Zephronia ovalis thus remains a mystery, and the best way to solve the problem is to designate a neotype in accordance with the recent use of the name Zephronia." We here choose a species that (1) fits the classical views of the genus by Pocock and Attems, (2) shows a characteristic colour pattern so far 

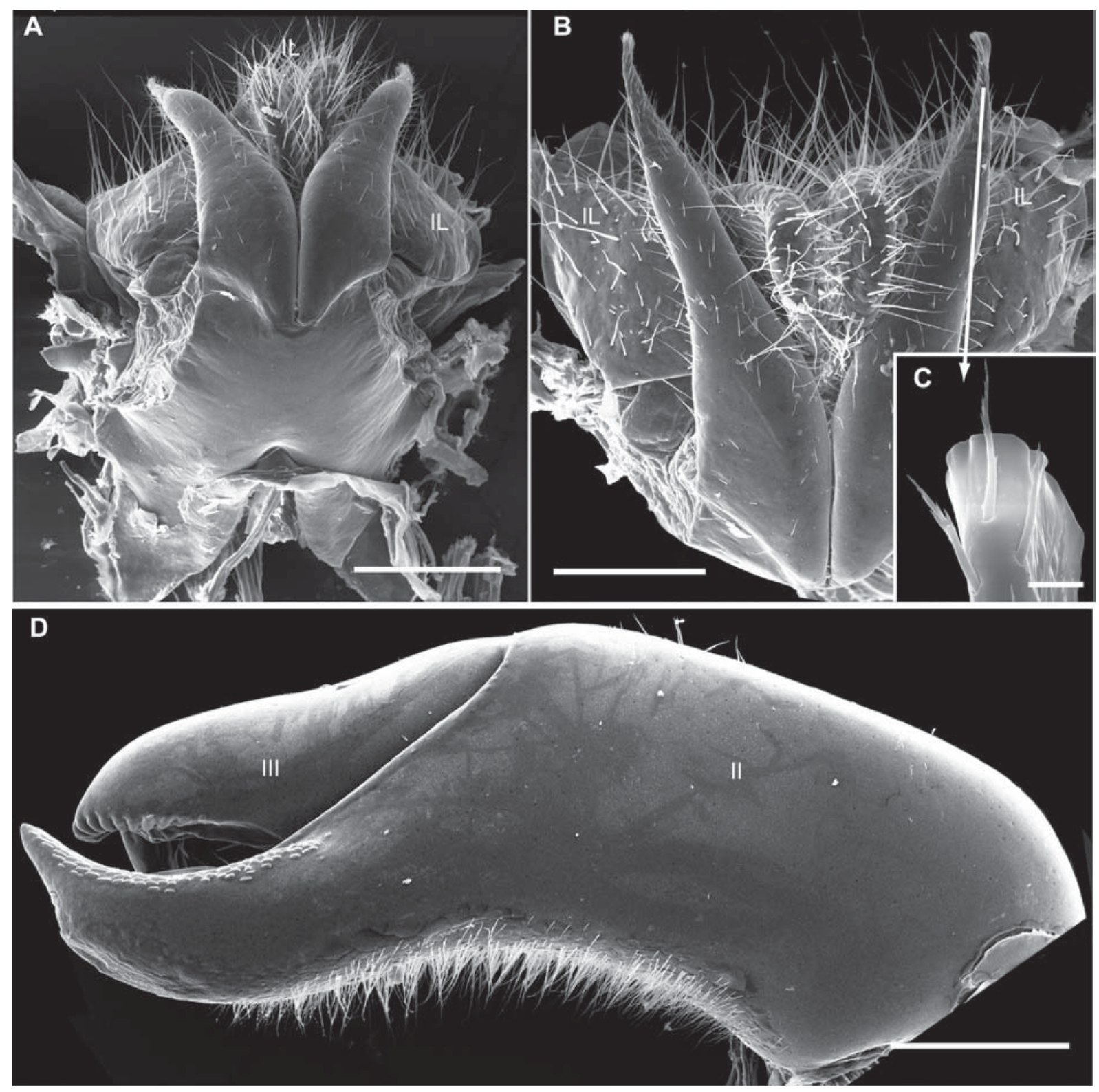

Fig. 10. Cryxus ovalis (Linnaeus, 1758), O7 (ZFMK MYR 0824), posterior telopod: A — inner horns of syncoxite, anterior view; B inner horns, tilted 45; C - detail of tip of right inner horn; D - posterior telopod, podomeres $2-4$, posterior view. Abbreviations: IL inner lobes; Roman numerals - podomere number. Scale bars: A $-0.4 \mathrm{~mm}$; B $-0.3 \mathrm{~mm}$; C $-0.01 \mathrm{~mm}$; D $-0.4 \mathrm{~mm}$.

Рис. 10. Cryxus ovalis (Linnaeus, 1758), О7 (ZFMK MYR 0824), задний телопод: А — внутренние рога синкоксита, спереди; В - внутренние рога при повороте на $45 ; \mathrm{C}$ - увеличенная вершина правого внутреннего рога; D - задний телопод, членики 24, сзади. Сокращения: IL — внутренние доли; римские цифры — номер членика. Масштаб: A — 0,4 мм; B — 0,3 мм; C - 0,01 мм; D - 0,4 мм.

unique for the order, (3) comes from a well-known, geo-referenced locality, (4) is available in the male and female sex, and (5) of which material is conserved well enough for DNA extraction.

A NEW DIAGNOSIS. Colour pattern unique in the order. Ground pattern dark olive-blackish, with two golden stripes dorsally running from thoracic shield to anal shield; thoracic shield laterally golden, except for margins; anal shield anteriorly and laterally on each side with a golden stripe (Figs 2C, D). Protrusion of brim of antennal groove into process separating organ of Tömösváry from ocelli other than in Z. ovalis has only been known so far in $Z$. siamensis.

REDESCRIPTION. Measurements: $\sigma^{7}: 14.7 \mathrm{~mm}$ long, tergite 2 (= thoracic shield), 6.8, tergite 8, 7.2 $\mathrm{mm}$ (widest) wide; tergite $2,4.2$, tergite 8 (highest), $4.6 \mathrm{~mm}$ high. $+17.5-18.9 \mathrm{~mm}$ long, tergite 2 (= thoracic shield), 5.5-8.7, tergite $8,9.2 \mathrm{~mm}$ (widest) 


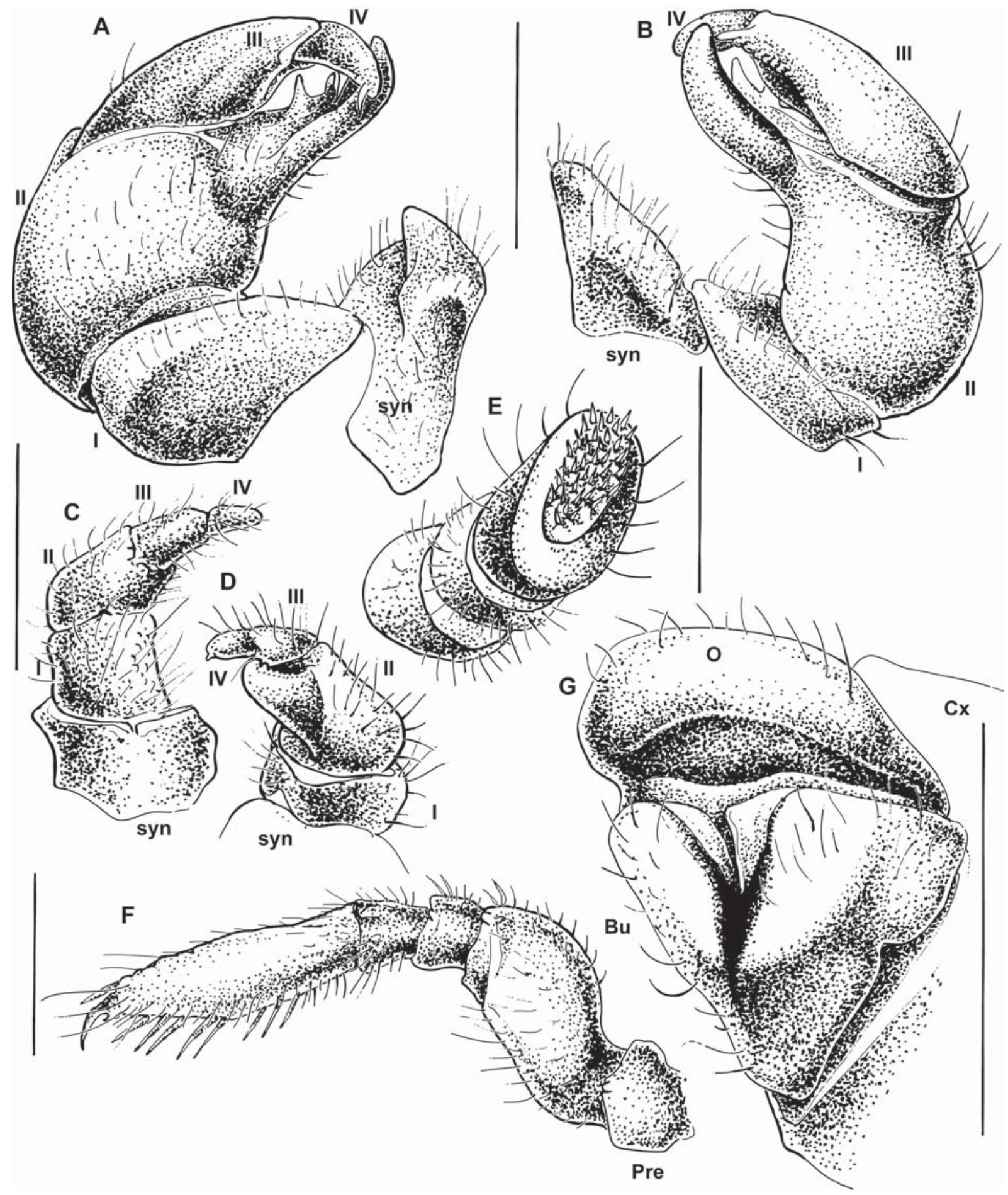

Fig. 11. Zephronia ovalis (Gray, 1832) (ZFMK MYR 0825 \& 0832): A — posterior telopod, anterior view; B - posterior telopod, posterior view; C - left half of anterior telopod, anterior view; D - left anterior telopod, posterior view; E — left antenna; F — left leg 10 (coxa missing), posterior view; $\mathrm{G}$ - left coxa 2 and prefemur 2 with vulva. Abbreviations: $\mathrm{Bu}$ - bursa; cr-t — crenulated teeth; $\mathrm{Cx}$ coxa; O - operculum; Pre - prefemur; syn - syncoxite; Roman numerals - number of podomere. Scale bars - $1.0 \mathrm{~mm}$.

Pис. 11. Zephronia ovalis (Gray, 1832) (ZFMK MYR 0825 \& 0832): A — задний телопод, спереди; В - задний телопод, сзади; С — левая половина переднего телопода, спереди view; D — левый передний телопод, сзади; Е — левая антенна; F — левая нога 10 без коксы, сзади; $\mathrm{G}$ - левые кокса 2 и префемур 2 с вульвой. Сокращения: $\mathrm{Bu}$ - сумка; cr-t — мелкозазубренные зубы; $\mathrm{Cx}$ - кокса; O — крышечка; Pre — префемур; syn - синкоксит; римские цифры — номер членика. Масштаб - 1,0 мм. 

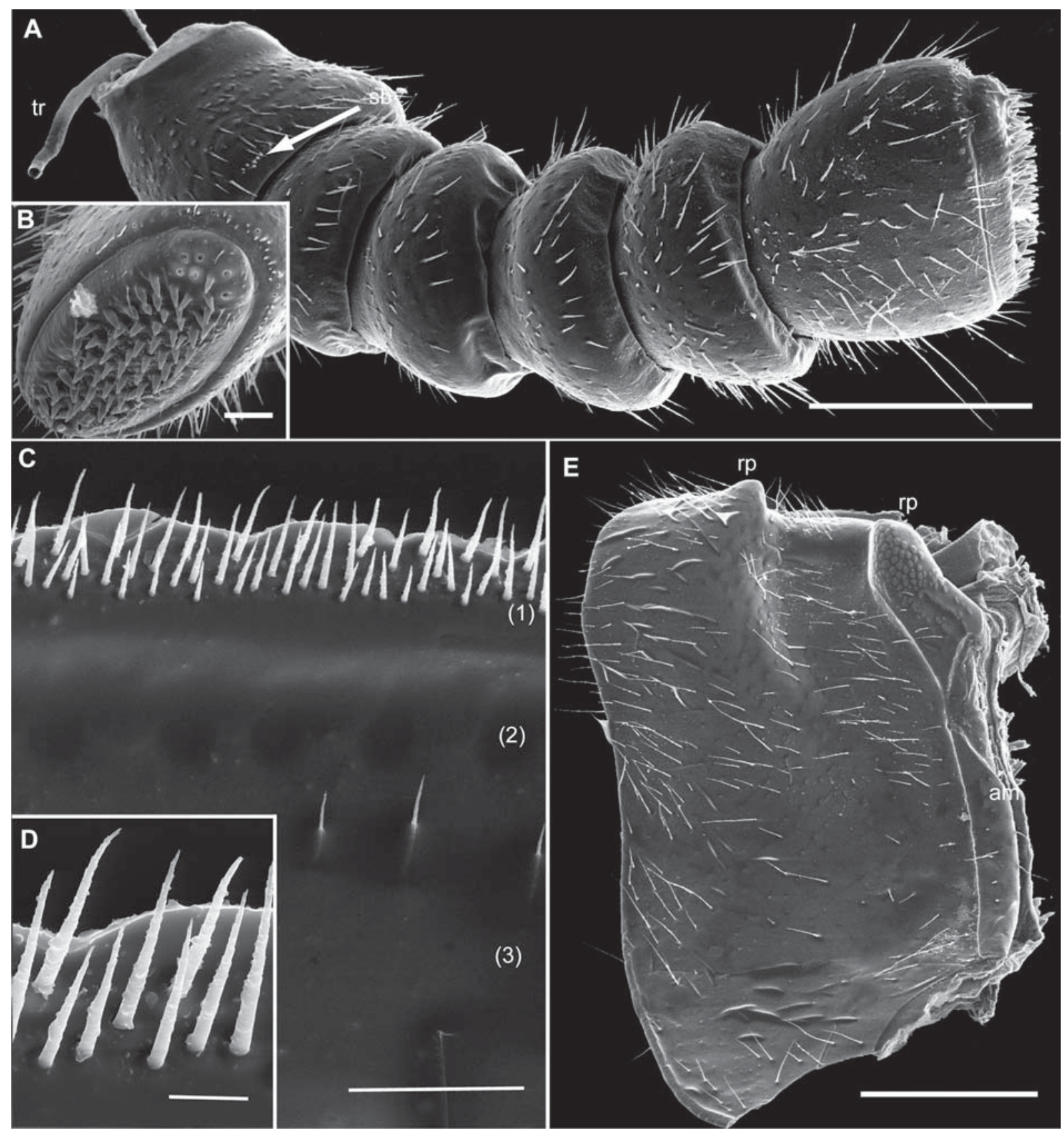

Fig.12. Zephronia ovalis (Gray, 1832) (ZFMK MYR 0832), SEM: A — right antenna; B — antenna, detail of disc; C — endotergum of midbody tergite; D — endotergum, marginal bristles; E — latero-tergite 5(1). Abbreviations: (1) — outer area with a row of setae; (2) — middle area with a crest and cuticular patterns; (3) — inner area; am — anterior margin; $\mathrm{rp}$ — round projection; sb — sensilla basiconica; tr - trachea. Scale bars: A $-0.5 \mathrm{~mm}$; B \& C $-0.1 \mathrm{~mm}$; D $-0.02 \mathrm{~mm}$; E $-0.6 \mathrm{~mm}$.

Pис. 12. Zephronia ovalis (Gray, 1832) (ZFMK MYR 0832), SEM: A — правая антенна; В - антенна, увеличенный диск; C эндотергум среднетуловищного тергита; D - эндотергум, краевые щетинки; Е — латеротергит 5(1). Сокращения: (1) - внешняя область с рядом щетинок; (2) - средняя область с ребром и кутикулярным рисунком; (3) - внутренняя область; ат — передний край; rp — округлый выступ; sb — sensilla basiconica; $\operatorname{tr}$ — трахея. Масштаб: A — 0,5 мм; В и C — 0,1 мм; D — 0,02 мм; E - 0,6 мм.

wide; tergite 2, 4.0-5.5, tergite 8 (highest), $6.0 \mathrm{~mm}$ high.

Body small, relatively slender, glabrous, usually dull, poorly shining at best (Figs 2D, E).

Coloration: antennae, legs, head, collum dark olive blackish. Thoracic shield (tergite 2) and tergites 3-12 dark olive blackish, dorsally with two golden-yellow stripes (Fig. 2C). Thoracic shield golden except for dorso-anterior corner and margins (Fig. 2D). Anal shield with a very large dark olive spot, only anterior part golden (Fig. 2C).

Head typical of the order. Ocellaria with ca 80 ocelli and a single isolated ocellus located inside antennal groove. Margin of antennal groove projecting like a 


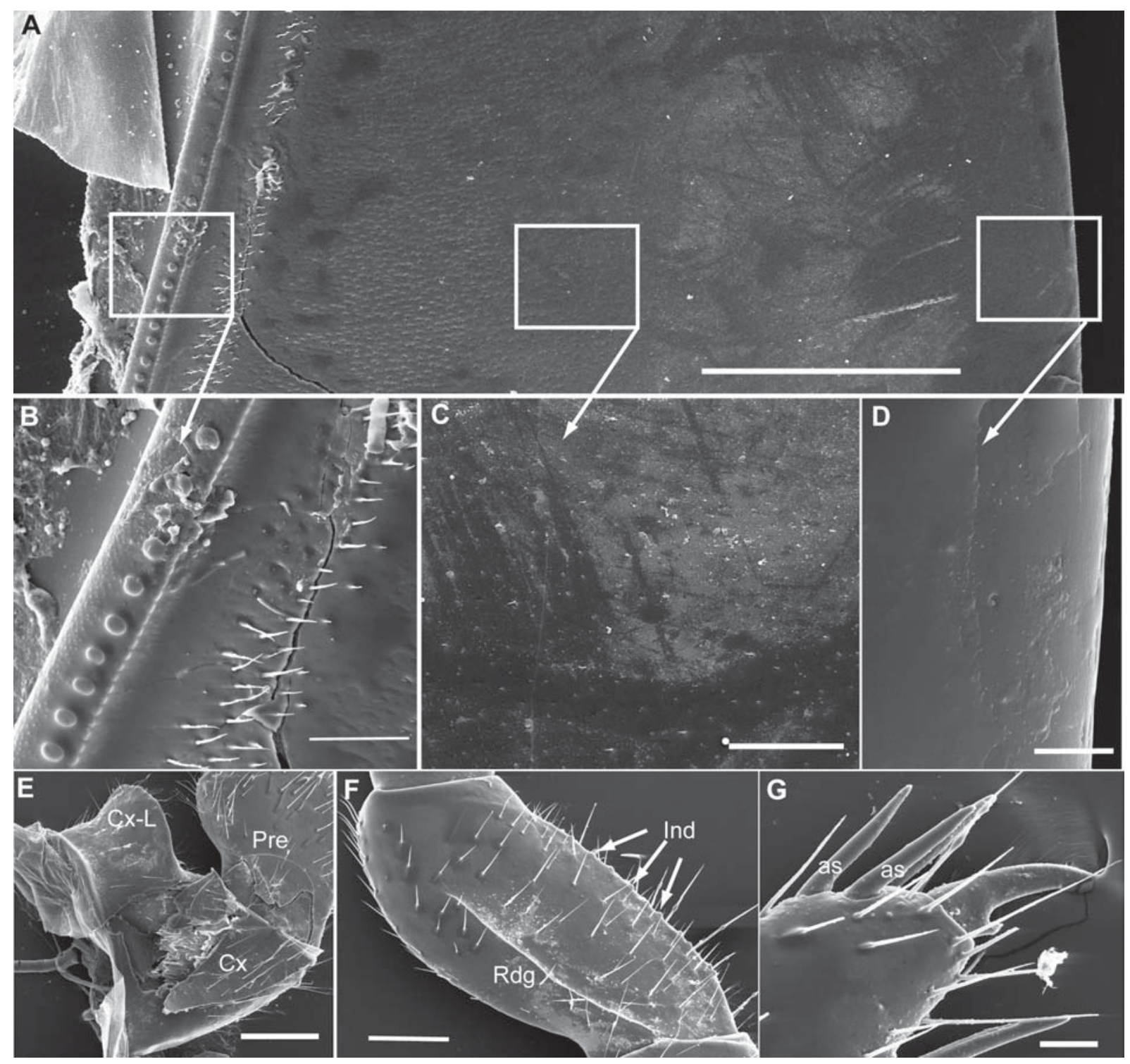

Fig. 13. Zephronia ovalis (Gray, 1832) (ZFMK MYR 0832), SEM: A — midbody tergite, dorsal surface, overview; B — midbody tergite, anterior margin; $\mathrm{C}$ - midbody tergite, middle part; D — midbody tergite, posterior margin (limbus); E — coxa 9 and prefemur 9; F - femur 9; G - apical part of tarsus 9. Abbreviations: as — apical spine(s); Cx — coxa; Cx-L — coxal lobe; Ind — indentations of femoral mesal margin; Pre — prefemur; Rdg — femoral ridge. Scale bars: A — $0.6 \mathrm{~mm} ; \mathrm{B}, \mathrm{C} \& \mathrm{G}-0.1 \mathrm{~mm}$; D $-0.02 \mathrm{~mm}$; E $-0.4 \mathrm{~mm}$; $\mathrm{F}-0.3 \mathrm{~mm}$.

Рис. 13. Zephronia ovalis (Gray, 1832) (ZFMK MYR 0832), SEM: A — среднетуловишный тергит, дорсальная поверхность, общий вид; В - среднетуловишный тергит, передний край; $\mathrm{C}$ - среднетуловишный тергит, средняя часть; D - среднетуловишный тергит, задний край (лимбус); Е - кокса 9 и префемур 9; F — фемур 9; G - апикальная часть тарсуса 9. Сокращения: as апикальные шипы; $\mathrm{Cx}$ — кокса; Cx-L — коксальная доля; Ind — зазубрины на внутреннем крае фемура; Pre — префемур; Rdg феморальный гребень. Масштаб: А - 0,6 мм; В, C, G - 0,1 мм; D - 0,02 мм; E - 0,4 мм; F - 0,3 мм.

wide crest, separating Tömösváry's organ from ocellaria. Posterior margin of head without field of small setae.

Antennae: length of antennomeres $1>2=3=4=5<<6$, last antennomere almost as large as two basal ones combined (Fig. 12A). First antennomere without a groove, but with rounded, sclerotized teeth and, apically, with 1 or 2 rows of sensilla basiconica (Fig. 12A). Antennomeres 1-5 much wider apically than basally (Fig. 12A). Antennomere 6 flattened laterally and twice as wide apically as basally (Figs 11E, 12B), towards disc with 1 or 2 rows of sensilla basiconica. Disc bearing 62-65 (smaller $\mathrm{O}^{7}$ ) or 71-73 (larger ${ }^{\text {) }}$ ) sensory cones (Figs 11E, 12B). Antennomeres 1-5 abundantly setose, with setae of varying lengths, longest ones reaching length of basal antennomeres.

Mandibles, gnathochilarium, hypopharynx and epipharynx not investigated due to paucity of material.

Collum (tergite 1) with anterior and posterior margins bearing numerous long setae, central part glabrous. 
Thoracic shield (tergite 2) glabrous except for lateral grooves carrying a few short setae. Grooves shallow and very narrow.

Tergites 3-12: surface_generally glabrous and dull. Body not much higher posteriorly than anteriorly. Paratergite tips straight, not projecting posteriorly (Fig. 2D). Anterior margin with an elevated crest, the latter with a single row of large, round, sclerotized grains (Fig. 13A). The crest followed by 3 or 4 relatively dense rows of setae (Fig. 13B) covered with the previous tergite and not visible in undissected specimens. Anterior half of tergites, especially dorsally, beset with minute, shallow pits (Fig. 12C). Surface of posterior margin (limbus) well-rounded, without peculiarities (Fig. 12D). Underside of each paratergite with a black, sclerotized, locking carina.

Endotergum (underside of posterior margin of tergite) with three rows of marginal bristles protruding beyond edge (Fig. 12C). Bristles short and smooth, arranged at regular distances from one another (Fig. 12D). Marginal ridge well-rounded, at inner margin with a single row of large, circular, cuticular impressions (Fig. 12C). Inner area without any spines, but with a few longer setae (Fig. 12C).

Anal shield glabrous, regularly rounded. Tergite 13 completely fused with anal shield, neither suture nor indentation visible. Underside carrying one short, black, locking carina located close to lateral margin.

Legs: $1^{\text {st }}$ and $2^{\text {nd }}$ with neither coxal lobe nor apical spine. Tarsi 1 with $1-3,2$ with $3-5,3$ with 5 , and midbody tarsi with 6-8 ventral spines, all widely dispersed in distal 2/3 (Fig. 11F). Legs 3-21 with 2 or 3 apical spines (Fig. 13G) and a large, well-rounded, coxal lobe (Fig. 13E). In leg 9, femur 1.8, tarsus 3.6 times longer than wide (Fig. 11F). Femur on posterior side in legs 1-21 with one long ridge, mesal margin irregular, with numerous indentations (Fig. 13F).

Stigmatic plates: $1^{\text {st }}$ stigmatic plate small, rounded, curved towards coxa, stigma opening located close to inner margin. $2^{\text {nd }}$ plate larger, with a lower area separating stigma opening from inner margin. Stigmatic plates 3-21 narrow, overlapped by latero-tergites, stigma opening protected by a coxal process.

Latero-tergites: $1^{\text {st }}$ latero-tergite elongated into a strongly tapering process. Latero-tergites 2-11 with two rounded projections directed towards tergite, anterior one covered with numerous sclerotized scales (Fig. 12E). Anterior margin elevated, entire surface beset with numerous long setae. Latero-tergite 12 smaller, well-rounded, without any projection.

Vulva with both basal plates (= bursa) fused, operculum surrounding bursa only apically. Operculum apically with a wide, well-rounded tip at inner margin, not protruding distally above coxa (Fig. 11G).

Subanal plate large, without ribs, undivided.

Male gonopore located at mesal margin, large, covering almost $2 / 3$ of margin. Gonopore covered with a basally sclerotized, apically membranous plate. Sclerotized part of plate carrying numerous long setae.
Distal to gonopore, a smoother, darker, more strongly sclerotized area.

Anterior telopods with four podomeres distal to syncoxite (Fig. 11C). Syncoxite glabrous except for a few long setae, divided into two halves by a weakly sclerotized white area. First podomere rectangular, in anterior view with numerous long setae, especially in meso-apical part (Fig. 11C). Second podomere tapering apically, surface with numerous long setae (Fig. 11C), posterior side with a long process (Fig. 11D). Process of second podomere wide, tapering apically, tip curved towards podomere 3 (Fig. 11D). Podomeres 3 and 4 small, cylindrical, both combined as long as podomere 2 (Fig. 11D). Podomere 3 juxtaposed to tip of process of podomere 2 , membranous, lateral margin with a row of 3 or 4 darker, sclerotized nodules (Fig. 11D). Podomeres 3 and 4 with few setae, tip of podomere 4 with a single short spine (Fig. 11D).

Posterior telopods of a shape usual for the order, with four podomeres distal to syncoxite (Fig. 11A). Syncoxite consisting of inner lobes and inner horns. Inner lobes densely pilose, tips projecting between inner horns. Inner horns consisting of a basal, glabrous half and two basally contiguous, but completely separated and projecting horns; both areas divided by a suture. Horns tapering apically; basally with a few, apically with numerous, setae.

First telopod podomere very wide, almost 2 times wider than long, glabrous like remaining podomeres except for margins (Fig. 11B). Second podomere massive, discarding immovable finger as long as wide (Figs 11A, B). Process of second podomere tapering towards tip, apical part slightly bent distad towards podomere 4 (Fig. 11B). The process long, protruding as much as podomere 4, relatively slender (Fig. 11B). Inner margin with a large membranous ledge and two large, triangular, membranous lobes arising from the ledge (Fig. 11A).

Third telopod podomere slightly tapering towards tip (Fig. 11A). Mesal margin with a large membranous ridge, three spines (one pair located near midlength, spine 3 apically), and 16 small, sclerotized, crenulated teeth (Fig. 11B). Fourth podomere small, less than half as long as $3^{\text {rd }}$, with two spines at inner margin, one located near midlength, the other close to tip (Fig. 11A). Apex of podomere 4 and process of podomere 2 in touch (Fig. 11B).

ACKNOWLEDGEMENTS. We are most grateful to A.E. Anichkin and A.V. Tiunov for having rendered us their collections of Diplopoda from Cat Tien for study. The Russian-Vietnamese Tropical Center provided financial support, and the Administration of the Cat Tien National Park the permits, for field work of two authors (SIG and IIS) in Vietnam. C. Etzbauer (ZFMK) thankfully conducted the molecular lab work. Holly Wesener kindly corrected the English. N. Wongthamwanich is thanked for a discussion and the deposition of Zephronia siamensis specimens at the Field Museum. 


\section{References}

Altschul S.F., Madden T.L., Schäffner A.A., Zhang J., Zhang Z., Miller W., Lipman D.J. 1997. Gapped BLAST and PSI-BLAST: a new generation of protein database search programs // Nucleic Acids Research. Vol.25. No.17. P.3389-3402.

Brandt J.F. 1833. Tentaminum quorundam monographicorum Insecta Myriapoda Chilognatha Latreillii spectantium prodromus // Bulletin de la Socété Impériale des Naturalistes de Moscou. T.6. P.194-209.

Brandt J.F. 1841. Remarques critiques sur les espèces qui composent les genres Sphaerotherium et Sphaeropoeus, suivies d'une description de six espèces nouvelles des Sphaerothéries // Bulletin scientifique publié par l'Académie Impériale des Sciences de St. Pétersbourg. T.8. Columns 357-365.

Brandt J. 1844. Critische Bemerkungen über die Sippen Sphaerotherium und Sphaeropoeus (Zephronia), Nebensippen von Glomeris // Isis von Oken. Bd.37. S.129.

Butler A.G. 1873. A monographic revision of the genera Zephronia and Sphaerotherium, with descriptions of new species // Proceedings of the Zoological Society, London. Vol.1873. P. $172-182$.

Fabricius J.C. 1775. Systema entomologiae. Flensburgi \& Lipsiae. $832 \mathrm{pp}$.

Fabricius J.C. 1781. Species Insectorum. Hamburgi. T.1. P.i-viii, $1-552$.

Fabricius J.C. 1793. Entomologia systematica emendata et aucta. Hafniae. T.2. P.i-viii, 1-519.

Felsenstein J. 1985. Confidence limits on phylogenies: An approach using the bootstrap // Evolution. Vol.39. P.783-791.

Folmer O., Black M., Hoeh W., Lutz R., Vrijenhoek R. 1994. DNA primers for amplification of mitochondrial cytochrome c oxidase subunit I from diverse metazoan invertebrates // Molecular Marine Biology and Biotechnology. Vol.3. No.5. P.294-299.

Gervais P. 1837. Études pour servir à l'histoire naturelle des Myriapodes // Annales des Sciences naturelles. Sér.2. T.7. P.35-60.

Gervais P. 1844. Études sur les Myriapodes // Annales des Sciences naturelles. Sér.3. Zoologie. T.2. P.51-80.

Gervais P. 1847. Myriapodes // Walckenaer C.A., Gervais P. (eds.) Histoire naturelle des Insectes. Aptères. Paris. T.4. P.1-623.

Golovatch S.I., Hoffman R.L. 2001. On the diplopod taxa and type material of J. F. Brandt, with some new descriptions and identities (Diplopoda) // Fragmenta Faunistica. Vol.43. Supplement. P.229-249 (for 2000).

Golovatch S.I., Tiunov A.V., Anichkin A.E. 2011. [Millipedes (Diplopoda)] // Tiunov A.V. (ed.). Struktura i funktsii pochvennogo naseleniya tropicheskogo mussonnogo lesa (natsional'niy park Kat Tien, Yuzniy Vietnam) [Structure and functions of soil communities of a monsoon tropical forest (Cat Tien National Park, southern Vietnam)]. Moscow: KMK Scientific Press. P.77-90 [in Russian, with English abstract].

Gray G. 1832. The Myriapods (Myriapoda - Mitosata) // Griffith E., Pidgeon E. (eds). The Class Insecta arranged by the Baron Cuvier. London. Vol.2. P.1-796.

Gray G. 1842. Myriapoda // Todd M.R. (ed.). The Cyclopaedia of Anatomy and Physiology. Vol.3. P.544-560.

Hall T.A. 1999. BioEdit: a user-friendly biological sequence alignment editor and analysis program for Windows 95/98/NT // Nucleid Acids Supplemental Series. Vol.41. P.95-98.

Hoffman R.L. 1980. Classification of the Diplopoda. Genève: Musée d'histoire naturelle. 237 pp. (for 1979).

Jeekel C.A.W. 1970. Nomenclator generum et familiarum Diplopodorum. A list of the genus and family-group names in the class Diplopoda from the 10th edition of Linnaeus, 1758, to the end of $1957 / /$ Monografieën van de Nederlandse Entomologische Vereiniging. No.5. P.i-xii, 1-412.

Jeekel C.A.W. 2001. A bibliographic catalogue of the Asiatic Sphaerotheriida (Diplopoda) // Myriapod Memoranda. Vol.3. P.5-38.

Klug F. 1810. Latreille's Genera Crustaceorum et Insectorum // Weber F. (Hrsg.). Beiträge zur Naturkunde. Kiel. Bd.2. S.217-238.
Koch C.L. 1847. System der Myriapoden, mit den Verzeichnissen und Berichtigungen zu Deutschlands Crustaceen, Myriapoden und Arachniden. Regensburg. 270 S.

Koch C.L. 1863. Die Myriapoden. Getreu nach den Natur abgebildet und beschrieben. Halle. Bd.2. S.i-vi, 1-112.

Lamarck J.B. 1858. Histoire naturelle des animaux sans vertèbres. Arachnides, Crustacés, Annelides, Cirrhipèdes. Paris. Ed.2. T.5. 1-699.

Latreille P.A. 1804. Histoire naturelle, générale et particulière, des Crustacés et des Insectes. Paris. T.7. P.1-415.

Latreille P.A. 1810. Considérations générales sur l'ordre naturel des animaux composant les classes des Crustacés, des Arachnides, et des Insectes. Paris. $444 \mathrm{pp}$.

Latzel R. 1884. Die Myriopoden der österreichisch-ungarischen Monarchie. Bd.2. S.i-vii, 1-414.

Leach W.E. 1814. Crustaceology, Myriapoda // Brewster D. (ed.). The Edinburgh Encyclopaedia. Vol.7. P.386-387, 407-409, 434-436, 765-766.

Leach W.E. 1817. The zoological miscellany; being descriptions of new or interesting animals. XII. The characters of the genera of the class Myriapoda, with descriptions of some species. Vol.3. P.31-45.

Linnaeus C. 1758. Systema naturae per regni tria naturae. Editio decima, reformata. Holmiae. T.1. 1-1384.

Linnaeus C. 1759. Amoenitates academicae. Holmiae. T.4. P.1600.

Linnaeus C. 1767. Systema naturae, per regni tria naturae. Editio decima tertia. Vindobonae. T.1. Pars 2. P.1-4120.

Linné C. von (= Linnaeus C.) 1775. Vollständiges Natursystem der Insecten. Nürnberg. Bd.2. S.i-93, 1-1066.

Linnaeus C. 1788a. Systema naturae per regni tria naturae. Editio decima tertia, aucta, reformata. Lipsiae. T.1. 1-3910.

Linnaeus C. 1788b. Amoenitates academicae. Erlangae. Ed.2. T.4. P.1-602.

Linnaeus C. 1789. Entomologia, faunae Suecicae descriptionibus aucta. Lugduni. T.4. P.i-ccxii, 1-556.

Lucas M. 1842. Histoire naturelle des Crustacés, des Arachnides et des Myriapodes. Paris: Duménil. $601 \mathrm{pp}$.

Nei M., Kumar S. 2000. Molecular Evolution and Phylogenetics. Oxford University Press, New York.

Newport G. 1844a. A list of the species of Myriapoda, Order Chilognatha, contained in the cabinets of the British Museum, with descriptions of a new genus and thirty-two new species // Annals and Magazine of Natural History. Vol.13. P.263-270.

Newport G. 1844b. List of the specimens of Myriapoda in the collection of the British Museum. London. $15 \mathrm{pp}$.

Newport G. 1856. Catalogue of the Myriapoda in the collection of the British Museum. Part 1. Chilopoda. London. 6 pp.

Odhelius J.L. 1754. Chinensia lagerstroemiana. Holmiae.

Oken L. 1835. Allgemeine Naturgeschichte für alle Stände. Stuttgart. Bd.5. Abt.2. S.539-1050.

Olivier A.G. 1792. Histoire naturelle. Insectes // Encyclopédie méthodique. T.7. P.1-827.

Olliff A.S. 1882. Description of a new species of the genus Zephronia, from Borneo // Cistula Entomologica. Vol.3. Pars 26. P.29-30.

Pocock R.I. 1895. Description of new genera of Zephronidae, with brief preliminary diagnoses of some new species // Annals and Magazine of Natural History. Ser.6. Vol.16. P.409-415.

Pocock R.I. 1899a. A monograph of the pill-millipedes (Zephroniidae) inhabiting India, Ceylon and Burma. Part I // Journal of the Bombay Natural History Society. Vol.12. P.269-285.

Pocock R.I. 1899b. A monograph of the pill-millipedes (Zephroniidae) inhabiting India, Ceylon and Burma. Part II // Journal of the Bombay Natural History Society. Vol.12. P.465-474.

Preudhomme de Borre A. 1884. Tentamen catalogi Glomeridarum hucusque descriptarum // Annales de la Société entomologique de Belgique. T.28. P.19-28.

Saiki R.K., Gelfand D.H., Stoffel S., Scharf S.J., Higuchi R., Horn G.T., Mullis K.B., Erlich H.A. 1988. Primer-directed enzymatic amplification of DNA with a thermostable DNA polymerase // Science. Vol.239. P.487-491. 
Simon C., Frati F., Beckenbach A., Crespi B., Liu H., Flook P. 1994. Evolution, weighting, and phylogenetic utility of mitochondrial gene-sequences and a compilation of conserved polymerase chain-reaction primers // Annals of the Entomological Society of America. Vol.88 P.651-701

Semenyuk I.I., Tiunov A.V., Golovatch S.I. 2011. Structure of mandibles in relation to trophic niche differentiation in a tropical millipede community // International Journal of Myriapodology. Vol.6. P.37-49.

Silvestri F. 1897. Systema Diplopodum // Annali del Museo Civico di Storia Naturale di Genova. Ser.2. Vol.16. P.644-651.

Swofford D. 2002. PAUP*. Phylogenetic Analysis Using Parsimony (*and Other Methods). Version 4.0 (Sinauer Associates: Sunderland, MA, USA.)

Tamura K., Peterson D., Peterson N., Stecher G., Nei M., Kumar S. 2011. MEGA5: Molecular Evolutionary Genetics Analysis using Maximum Likelihood, Evolutionary Distance, and Maximum
Parsimony Methods // Molecular Biology and Evolution. Vol.28. P.2731-2739.

Wesener T., VandenSpiegel D. 2009. A first phylogenetic analysis of Giant Pill-millipedes (Diplopoda: Sphaerotheriida), a new model Gondwanan taxon, with special emphasis on island gigantism // Cladistics. Vol.25. P.1-9.

Wesener T., Raupach M.J., Sierwald P. 2010. The origins of the Giant Pill-Millipedes from Madagascar (Diplopoda: Sphaerotheriida: Arthrosphaeridae) // Molecular Phylogenetics and Evolution. Vol.57. P.1184-1193.

Wongthamwanich N., Panha S., Sierwald P., Wesener T., Thirakhupt K. 2012. A new species of the giant pill-millipede genus Sphaerobelum Verhoeff, 1924 from northern Thailand, with an extensive description and molecular characters (Diplopoda: Sphaerotheriida: Zephroniidae) // Zootaxa. No.3220. P.29-43.

Responsible editor K.G. Mikhailov 